DNA Library of Life, research article

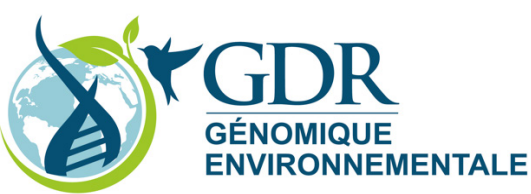

urn:1sid:zoobank.org:pub:2C4F928F-5EB7-494C-950A-3BAF99369F93

\title{
Documenting tenebrionid diversity: progress on Blaps Fabricius (Coleoptera, Tenebrionidae, Tenebrioninae, Blaptini) systematics, with the description of five new species
}

\author{
Laurent SOLDATI ${ }^{1, *}$, Fabien L. CONDAMINE ${ }^{2}$, \\ Anne-Laure CLAMENS ${ }^{3}$ \& Gael J. KERGOAT ${ }^{4, *}$ \\ 1,2,3,4 INRA - UMR 1062 CBGP (INRA, IRD, CIRAD, Montpellier SupAgro), \\ 755 Avenue du Campus Agropolis, 34988 Montferrier-sur-Lez, France. \\ ${ }^{2}$ CNRS - UMR 5554 Institut des Sciences de l'Evolution (Université de Montpellier), \\ Place Eugène Bataillon, 34095 Montpellier, France. \\ *Corresponding authors: laurent.soldati@inra.fr (LS) and gael.kergoat@inra.fr (GJK) \\ ${ }^{2}$ Email: fabien.condamine@gmail.com \\ ${ }^{3}$ Email: anne-laure.clamens@inra.fr \\ ${ }^{1}$ urn:Isid:zoobank.org:author:B1795703-9439-4572-BC41-C01171062B7D \\ ${ }^{2}$ urn:Isid:zoobank.org:author:27BF116A-15A1-4D4C-A259-B5D9059A578C \\ ${ }^{3}$ urn:Isid:zoobank.org:author:D0ABC503-75A3-4DB4-9409-6F308124A1E1 \\ ${ }^{4}$ urn:Isid:zoobank.org:author:2F61F799-F919-42CA-927B-3712DB88AD04
}

\begin{abstract}
With about 250 species, the genus Blaps Fabricius, 1775 is one of the most diverse genera of darkling beetles (Coleoptera: Tenebrionidae: Tenebrioninae: Blaptini: Blaptina). In this study, we provide new insights on the evolutionary relationships of Blaps species using a combined molecular and morphological dataset encompassing 69 distinct Blaps species and subspecies (105 specimens in total, all belonging to the subgenus Blaps), four other representatives of the tribe Blaptini (from the subtribes Gnaptorina, Gnaptorinina and Prosodina) and 12 outgroup species. Five new species of Blaps are also described within the subgenus Blaps: $B$. effeminata sp. nov. from Libya, $B$. intermedia sp. nov. from Morocco, B. maldesi sp. nov. from Algeria, B. nitiduloides sp. nov. from Algeria and Tunisia and B. teocchii sp. nov. from Tunisia. The results of the phylogenetic analyses indicate that the genus Blaps is likely paraphyletic; the two highlighted clades are morphologically distinct and correspond to groups previously referred to as sections (I and II) within the subgenus Blaps. This suggests the need for more phylogenetic studies in order to clarify the status of the various genera and subgenera belonging to the tribe Blaptini.
\end{abstract}

Keywords. Blaps, molecular phylogenetics, morphology, taxonomy, Tenebrionidae.

Soldati L., Condamine F.L., Clamens A.-L. \& Kergoat G.J. 2017. Documenting tenebrionid diversity: progress on Blaps Fabricius (Coleoptera, Tenebrionidae, Tenebrioninae, Blaptini) systematics, with the description of five new species. European Journal of Taxonomy 282: 1-29. http://dx.doi.org/10.5852/ejt.2017.282 


\section{Introduction}

The species-rich darkling beetle family (Coleoptera: Tenebrionidae) encompasses ca 20000 described species worldwide (Ślipiński et al. 2011). The family currently consists of nine subfamilies, 96 tribes and 2300 genera (Matthews et al. 2010), some of which are highly diverse (e.g., the genus Strongylium Kirby, 1819 encompasses more than 1000 species). One of these species-rich genera is Blaps Fabricius, 1775, which belongs to the tribe Blaptini Leach, 1815 within the polyphyletic subfamily Tenebrioninae Latreille, 1802 (Kergoat et al. 2014a, 2014b). The tribe Blaptini consists of about 500 species, divided into five subtribes and 28 genera (Medvedev 2001, 2007; Medvedev \& Merk1 2002). Half of the tribe's species diversity is made up by the genus Blaps (ca 250 species; Löbl et al. 2008: 219-228), which belongs to the subtribe Blaptina Leach, 1815. Interestingly, new species of Blaps are regularly described, even from well-prospected areas such as Spain (Martinez Fernández 2010; Castro Tovar 2014). Most species of Blaps (i.e., 230) are from the subgenus Blaps Fabricius, 1775, whereas the remaining species are found in the subgenera Arenoblaps Medvedev, 1999, Dineria Motschulsky, 1860 and Prosoblapsia Skopin \& Kaszab, 1978 (Löbl et al. 2008). All these subgenera represent conspicuous elements of Western and Central Asian beetle biodiversity; because these areas encompass the highest level of species and genus diversity within Blaptini, they are generally considered as the tribe's centre of origin and diversification (Medvedev 2000; Condamine et al. 2013). Representatives of the subgenus Blaps have the largest area of distribution as they are also found in the Mediterranean Basin (Condamine et al. 2011, 2013). Within the subgenus Blaps, two distinct groups - referred to as sections by Seidlitz (1893) have been recognized on the basis of specific morphological features (Solier 1848; Allard 1880, 1881, 1882; Seidlitz 1893; Gebien 1937). Recent phylogenetic analyses relying on either morphological only datasets (Condamine et al. 2011) or molecular and morphological datasets (Condamine et al. 2013) tend to support the hypothesis that both groups constitute monophyletic sister groups.

All species of Blaps are flightless and well adapted to semi-arid and arid environments because of several specific behavioural and morphological adaptations (Condamine et al. 2011). Subspecies of Blaps are generally morphologically well differentiated and may constitute species of their own (Ardoin 1973; Soldati 1994; Soldati et al. 2009; Condamine et al. 2011), as underlined by recent molecular phylogenetic analyses (Condamine et al. 2013). Previous biogeographical analyses found that geological events played an important role in their evolutionary history (Condamine et al. 2013). Because of their flightless habit, species of Blaps have limited dispersal abilities; in the context of the Mediterranean Basin, both the topographical and environmental heterogeneity, and the geographic isolation of many mountainous areas made them very prone to allopatric speciation (vicariance). This complex biogeographic context parallels the convoluted history of the taxonomy of Blaptini where numerous taxa have been alternatively treated as species or subspecies.

In this study, we conduct phylogenetic analyses relying on the largest dataset ever assembled for the subgenus Blaps (105 specimens belonging to 69 distinct species and subspecies are included), which includes three species that were not sampled in the study of Condamine et al. (2013). In contrast with the 2013 study, this dataset also includes four representatives of other Blaptini genera (Gnaptor Brullé, 1832, Gnaptorina Reitter, 1887 and Prosodes Eschscholtz, 1829), which belong to the subtribes Gnaptorina Medvedev, 2001 (genus Gnaptor), Gnaptorinina Medvedev, 2001 (genus Gnaptorina) and Prosodina Skopin, 1960 (genus Prosodes). To root the tree, we used 12 tenebrionid species as outgroups (Table 1). For this study, we assess the phylogenetic relationships of the subgenus Blaps, and we also include the description of five new species of Blaps from the Mediterranean Basin. 
Table 1. Taxon sampling. For each species and subspecies, the avialability of morphological data (the 'Morpho.' column) and the number of sequenced specimens are indicated. Additional taxonomic information for species of Blaps is also provided (section and species group for members of section I). [continued on next page]

\begin{tabular}{|c|c|c|c|c|}
\hline Species/subspecies & Morpho. & $\begin{array}{c}\text { \# of seq. } \\
\text { specimens }\end{array}$ & Section & Species group \\
\hline Blaps alternans Brullé, 1938 & yes & 1 & $\bar{I}$ & alternans \\
\hline Blaps inflata Allard, 1880 & yes & 2 & I & alternans \\
\hline Blaps maroccana Seidlitz, 1893 & yes & 2 & I & alternans \\
\hline Blaps ovipennis Seidlitz, 1893 & yes & 1 & I & alternans \\
\hline Blaps quedenfeldtii Seidlitz, 1893 & yes & 3 & I & alternans \\
\hline Blaps antennalis Allard, 1880 & yes & 0 & I & alternans \\
\hline Blaps tingitana Allard, 1880 & yes & 1 & I & alternans \\
\hline Blaps bifurcata mirei Gridelli, 1952 & yes & 1 & I & bifurcata \\
\hline Blaps bifurcata strauchii Reiche, 1861 & yes & 3 & I & bifurcata \\
\hline Blaps superstitiosa Erichson, 1841 & yes & 1 & I & bifurcata \\
\hline Blaps cognata Solier, 1848 & yes & 1 & I & cordicollis \\
\hline Blaps cordicollis Solier, 1848 & yes & 0 & I & cordicollis \\
\hline Blaps judaeorum Miller, 1858 & yes & 1 & I & cordicollis \\
\hline Blaps kaifensis Seidlitz, 1893 & yes & 0 & I & cordicollis \\
\hline Blaps kollarii Seidlitz, 1893 & yes & 2 & I & cordicollis \\
\hline Blaps appendiculata Motschulsky, 1851 & yes & 2 & I & emondi \\
\hline Blaps binominata Escalera, 1914 & yes & 1 & I & emondi \\
\hline Blaps debdouensis Obenberger, 1914 & yes & 2 & I & emondi \\
\hline Blaps emondi Solier, 1848 & yes & 2 & I & emondi \\
\hline Blaps intermedia Soldati sp. nov. & yes & 2 & I & emondi \\
\hline Blaps maldesi Soldati sp. nov. & yes & 1 & I & emondi \\
\hline Blaps nitiduloides Soldati sp. nov. & yes & 1 & I & emondi \\
\hline Blaps prodigiosa Erichson, 1841 & yes & 2 & I & emondi \\
\hline Blaps teocchii Soldati sp. nov. & yes & 0 & I & emondi \\
\hline Blaps approximans Seidlitz, 1893 & yes & 2 & I & gigas \\
\hline Blaps divergens Fairmaire, 1875 & yes & 1 & I & gigas \\
\hline Blaps doderoi Schuster, 1922 & yes & 2 & I & gigas \\
\hline Blaps effeminata Soldati sp. nov. & yes & 3 & I & gigas \\
\hline Blaps gigas Linnaeus, 1767 & yes & 4 & I & gigas \\
\hline Blaps haberti Peyerimhoff, 1943 & yes & 1 & I & gigas \\
\hline Blaps nefrauensis nefrauensis Seidlitz, 1893 & yes & 1 & I & gigas \\
\hline Blaps nefrauensis vespertina Koch, 1937 & yes & 2 & I & gigas \\
\hline Blaps polychresta Forskål, 1775 & yes & 1 & I & gigas \\
\hline Blaps taeniolata Ménétriés, 1832 & yes & 2 & I & gigas \\
\hline Blaps wiedemannii Solier, 1848 & yes & 1 & I & gigas \\
\hline Blaps bedeli Chatanay, 1914 & yes & 0 & I & lusitanica \\
\hline Blaps hispanica Solier, 1848 & yes & 1 & I & lusitanica \\
\hline Blaps lusitanica Herbst, 1799 & yes & 1 & I & lusitanica \\
\hline
\end{tabular}


Table 1. [continued from previous page; continued on next page]

\begin{tabular}{|c|c|c|c|c|}
\hline Species/subspecies & Morpho. & $\begin{array}{c}\text { \# of seq. } \\
\text { specimens }\end{array}$ & Section & Species group \\
\hline Blaps torressalai Español, 1961 & yes & 0 & I & lusitanica \\
\hline Blaps tichyi Martínez Fernández, 2010 & no & 1 & I & lusitanica \\
\hline Blaps waltlii Seidlitz, 1893 & yes & 1 & I & lusitanica \\
\hline Blaps magica Erichson, 1841 & yes & 0 & I & magica \\
\hline Blaps plana Solier, 1848 & yes & 3 & I & magica \\
\hline Blaps murati Peyerimhoff, 1943 & yes & 0 & I & murati \\
\hline Blaps nitens barbara Solier, 1848 & yes & 2 & I & nitens \\
\hline Blaps nitens brachyura Küster, 1848 & yes & 1 & I & nitens \\
\hline Blaps nitens medvedevi Soldati et al., 2009 & yes & 2 & I & nitens \\
\hline Blaps nitens mercatii Canzoneri, 1969 & yes & 1 & I & nitens \\
\hline Blaps nitens nitens Laporte, 1840 & yes & 3 & I & nitens \\
\hline Blaps nitens requieni Solier, 1848 & yes & 1 & I & nitens \\
\hline Blaps sulcifera Seidlitz, 1893 & yes & 2 & I & nitens \\
\hline Blaps megalatlantica Koch, 1945 & yes & 2 & I & peyerimhoffi \\
\hline Blaps pauliani Koch, 1945 & yes & 1 & I & peyerimhoffi \\
\hline Blaps peyerimhoffi Koch, 1945 & yes & 2 & I & peyerimhoffi \\
\hline Blaps pinguis Allard, 1880 & yes & 1 & I & pinguis \\
\hline Blaps propheta fiorii Español, 1967 & yes & 1 & I & propheta \\
\hline Blaps propheta propheta Reiche, 1861 & yes & 2 & I & propheta \\
\hline Blaps pubescens Allard, 1880 & yes & 3 & I & propheta \\
\hline Blaps ruhmeri Seidlitz, 1893 & yes & 1 & I & propheta \\
\hline Blaps tripolitanica Karsch, 1881 & yes & 2 & I & propheta \\
\hline Blaps dentitibia Reitter, 1889 & no & 1 & II & - \\
\hline Blaps femoralis medusula Skopin, 1964 & no & 1 & II & - \\
\hline Blaps gibba Laporte de Castelnau, 1840 & no & 1 & II & - \\
\hline Blaps inflata Allard, 1880 & no & 1 & II & - \\
\hline Blaps jeannei Ferrer \& Soldati, 1999 & yes & 1 & II & - \\
\hline Blaps lethifera Marsham, 1802 & yes & 1 & II & - \\
\hline Blaps mucronata Latreille, 1804 & yes & 1 & II & - \\
\hline Blaps plana Solier, 1848 & no & 1 & II & - \\
\hline Blaps rugosa Gebler, 1825 & no & 1 & II & - \\
\hline Blaps tibialis Reiche \& Saulcy, 1857 & no & 1 & II & - \\
\hline Gnaptor prolixus Fairmaire, 1866 & no & 1 & - & - \\
\hline Gnaptor spinimanus Pallas, 1781 & yes & 1 & - & - \\
\hline Gnaptorina cylindricollis Reitter, 1889 & no & 1 & - & - \\
\hline Prosodes jakowlewi Semenov, 1894 & yes & 1 & - & - \\
\hline Accanthopus velikensis Piller \& Mitterpacher, 1783 & no & 1 & - & - \\
\hline Dendarus coarcticollis Mulsant, 1854 & no & 1 & - & - \\
\hline Helops caeruleus Linnaeus, 1758 & no & 1 & - & - \\
\hline Helops rossii Germar, 1817 & no & 1 & - & - \\
\hline
\end{tabular}


Table 1. [continued from previous page]

\begin{tabular}{ccccc}
\hline Species/subspecies & Morpho. & $\begin{array}{c}\text { \# of seq. } \\
\text { specimens }\end{array}$ & Section & Species group \\
\hline Nalassus dryadophilus Mulsant, 1854 & no & 1 & - & - \\
Nalassus harpaloides Küster, 1850 & no & 1 & - & - \\
Platydema sp. & no & 1 & - & - \\
Scaurus atratus Fabricius, 1775 & no & 1 & - & - \\
Scaurus striatus Fabricius, 1792 & no & 1 & - & - \\
Scaurus uncinus Forster, 1771 & no & 1 & - & - \\
Uloma artensis Perroud, 1864 & no & 1 & - & - \\
Uloma rufa Piller \& Mitterpacher, 1783 & no & 1 & - & - \\
\hline
\end{tabular}

\section{Material and methods}

\section{Taxon sampling and morphological study}

Most specimens were acquired during field missions or through loans (see Condamine et al. 2011, 2013 for more details). Collected insects were identified by comparison with types and specimens housed in the following museums and private collections:

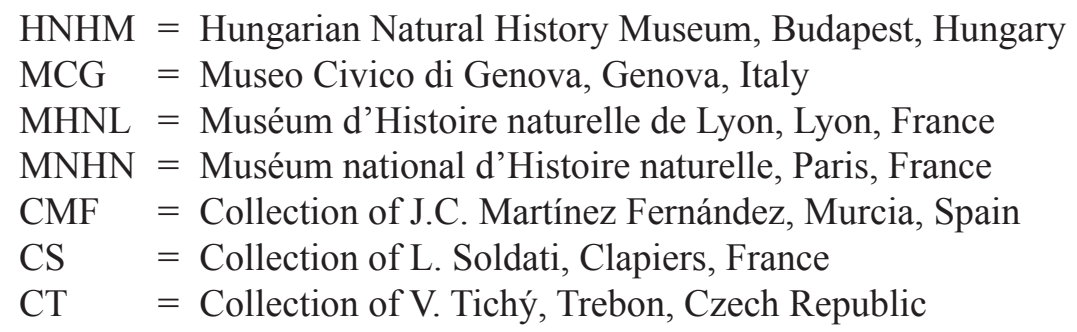

Holotypes of the new species were deposited in the MNHN, whereas paratypes were deposited in HNHM, MCG, MNHN, CMF, CS and CT. Photographs of specimens were taken using a Canon EOS 450D digital single-lens reflex camera fitted with an EF-S $60 \mathrm{~mm}$ macro lens. Photographs of male aedeagi were taken using EntoVision multifocus system.

In the Material examined sections, literal quotes from labels are placed within quotation marks.

\section{Morphological dataset}

The morphological dataset corresponds to the one published in the study of Condamine et al. (2011, see Appendix). This dataset consists of 47 morphological characters that have been scored for 62 species and subspecies of Blaps plus two other members of the tribe Blaptini (Gnaptor spinimanus (Pallas, 1781) and Prosodes jakowlewi Semenov, 1894). It is based on the examination of more than 2500 specimens; all characters are discrete, and multistate characters were treated as unordered (the annotated dataset is deposited in MorphoBank, homology of phenotypes over the web, under project number 2341, available from http://dx.doi.org/10.7934/P2341; see also http://morphobank.org/index.php).

\section{Molecular dataset}

The molecular dataset is based on that presented in the study of Condamine et al. (2013). The sampling for the tribe Blaptini is more comprehensive in the present study as it includes sequence data for five new species of Blaps and four other members of the tribe (see details below). It consists of four mitochondrial gene fragments: cytochrome oxidase I (COI), cytochrome b (Cytb), ribosomal 12S RNA (12S), and 
ribosomal 16S RNA (16S) (see Condamine et al. 2013 for the list of primers). Additional sequences were also obtained for five species (Blaps pinguis Allard, 1880, B. tichyi Martínez, 2010, Gnaptor prolixus Fairmaire, 1866, G. spinimanus and Prosodes jakowlewi) following the protocols described in Condamine et al. (2013). Newly generated PCR products were processed by Genoscope (France); all corresponding sequences were deposited in GenBank (see Appendix for accession numbers). In addition, we also used sequences available on GenBank for four species (Blaps dentitibia Reitter, 1889, B. femoralis medusula Skopin, 1964, B. rugosa Gebler, 1825 and Gnaptorina cylindricollis Reitter, 1889). In total, 112 specimens (96 of Blaps, four other representatives of the Blaptini tribe and 12 outgroup species) were included in the molecular dataset, with a total of 2011 aligned characters.

\section{Phylogenetic analyses}

Bayesian inference was used to infer phylogenetic relationships from a dataset combining the morphological and molecular matrices. This combined dataset encompasses 121 individuals (105 members of the genus Blaps, four other representatives of the Blaptini tribe and 12 outgroup species), of which nine are only included based on morphological characters. To improve the phylogenetic accuracy, we carried out partitioned analyses (Nylander et al. 2004). Partitions and substitution models for the molecular subset of the matrix were determined using PartitionFinder v. 1.1.1 (Lanfear et al. 2012). The Bayesian information criterion (BIC) was used for both partition and model selection (Ripplinger \& Sullivan 2008). Based on the BIC results we used five partitions for the molecular subset (Table 2). For the morphological data subset, we used an evolutionary model analogous to the JC69 model, except that it has a variable number of states (one-parameter Markov k-state model; Lewis 2001). Bayesian inference analyses were then carried out using MrBayes v. 3.2.6 (Ronquist et al. 2012). We conducted two independent runs with four MCMC (one cold and three incrementally heated) that ran for 50 million generations, with trees sampled every 5000 generations. A conservative burn-in of $25 \%$ was then applied after checking for stability on the log-likelihood curves and the split-frequencies of the runs. Support of nodes for MrBayes analyses was provided by clade posterior probabilities (PP) as directly estimated from the majority-rule consensus topology. Nodes supported by PP $\geq 0.95$ were considered strongly supported following Erixon et al. (2003).

\section{Results}

\section{Taxonomic descriptions}

Class Hexapoda Blainville, 1816

Order Coleoptera Linnaeus, 1758

Family Tenebrionidae Latreille, 1802

Blaps Fabricius, 1775

Blaps effeminata Soldati sp. nov. urn:1sid:zoobank.org:act:1D90B029-4826-4525-9A59-22B6B0A91806

Fig. 1A-I

\section{Etymology}

The name of this species refers to the lack of abdominal hair tufts in males.

\section{Material examined}

Holotype

LIBYA: O,, "Tombe a Nord di Cirene / Cirenaica, 27.IV.1967, G. Dellacasa \& P. Maifredi / Museo Civico di Genova / Blaps polychresta ssp. effeminata Soldati, Holotype" (MCG). 
Table 2. Results of PartitionFinder analyses, based on the BIC.

\begin{tabular}{cc}
\hline Partitions & Models \\
\hline \#1: COI_pos1, Cytb_pos1 & GTR $+\mathrm{G}$ \\
\#2: COI_pos2 & GTR $+\mathrm{G}$ \\
\#3: COI_pos3, Cytb_pos3 & GTR $+\mathrm{G}$ \\
\#4: Cytb_pos2 & GTR $+\mathrm{G}$ \\
\#5: 12S, 16S & GTR $+\mathrm{G}$ \\
\hline
\end{tabular}

\section{Allotype}

LIBYA: + , "Tombe a Nord di Cirene / Cirenaica, 27.IV.1967, G. Dellacasa \& P. Maifredi / Museo Civico di Genova / Blaps polychresta ssp. effeminata Soldati, Allotype" (MCG).

\section{Paratypes}

LIBYA: 17 spec., "Cirene, Cir. 7.6.1936 R.e C. Koch" (HNHM); 16 spec., same data as holotype and

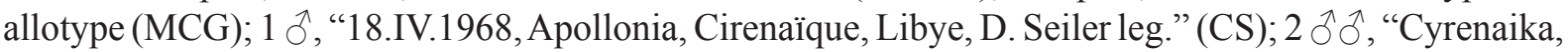
Cirene, Wohlb. 4.34" (CS); 1 +, "Tombe a Nord di Cirene / Cirenaica, 27.IV.1967, G. Dellacasa \& P. Maifredi" (CS).

Other material (13 specimens, HNHM; 8 specimens, MCG) LIBYA: Cyrene, E Libya, (HNHM); Sho-Hat (HNHM); Al Baida, 32³8.047' N, 214․ 425' E (MCG); Al Qubbah, Cyrene, Marsa (Tobruch) (MCG); Uadi el Magrum, E Libya, 15 km W of Tobruch (MCG); Uadi Pescara, E Libya, $16 \mathrm{~km}$ W of Tobruch (MCG).

\section{Description}

Length: 26.0-43.0 mm; width: 12.0-15.0 mm. Dull black. Oval-oblong, elongated (Fig. 1A-C). Elytra costulated. Upper surface covered with very fine and sparse punctures, progressively denser from elytra to head.

HEAD. Clypeus arcuately emarginated, with lateral angles protruding frontwards, clypeo-labial membrane slightly visible. Clypeo-frontal suture reduced to thin, superficially engraved glossy line. Middle of frons (disc) with faint, generally obliterated, transverse depression. Mentum transverse, punctate, with anterior third sloping toward anterior edge. Gula microshagreened, dull. Labium triangularly emarginated in middle of front edge.

AntennAe. Long and slender, reaching pronotal base when directed backwards (Fig. 1D).

Pronotum. Broadest in its middle, sides more strongly narrowed toward base than forward, not or barely sinuous before posterior angles and arcuately narrowed frontwards. Anterior angles rounded. Posterior angles blunt. External rim fine, complete on lateral margins, but obliterated in middle of front edge and base. Disc convex. Punctation fine, uniform. Carina of anterior foramen of pronotum thick and neckshaped below. Episternum of prosternum wrinkled near coxae and lighter toward margins. Prosternal apophysis oblique or steep and upright towards apex, S-shaped, just behind anterior coxae, then shortly denticulate in middle at apex.

ELYTRA. Ovoid, broadest around its middle, flat on disc. Upper surface leathery and covered with extremely fine and sparse punctures. Elytra costulate. Each elytron bearing 10 costae, alternate ones (3-5-7-9) slightly higher than others. Pseudopleural carina only visible on anterior half (in $\widehat{\partial} \widehat{\delta}$ and 우) from above, because of transversal convexity of elytra. Caudal extension at apex of elytra (mucro) measuring between 2.0 and $4.0 \mathrm{~mm}$. Seen from above, right, parallel: deep suture flanked by two thick, 

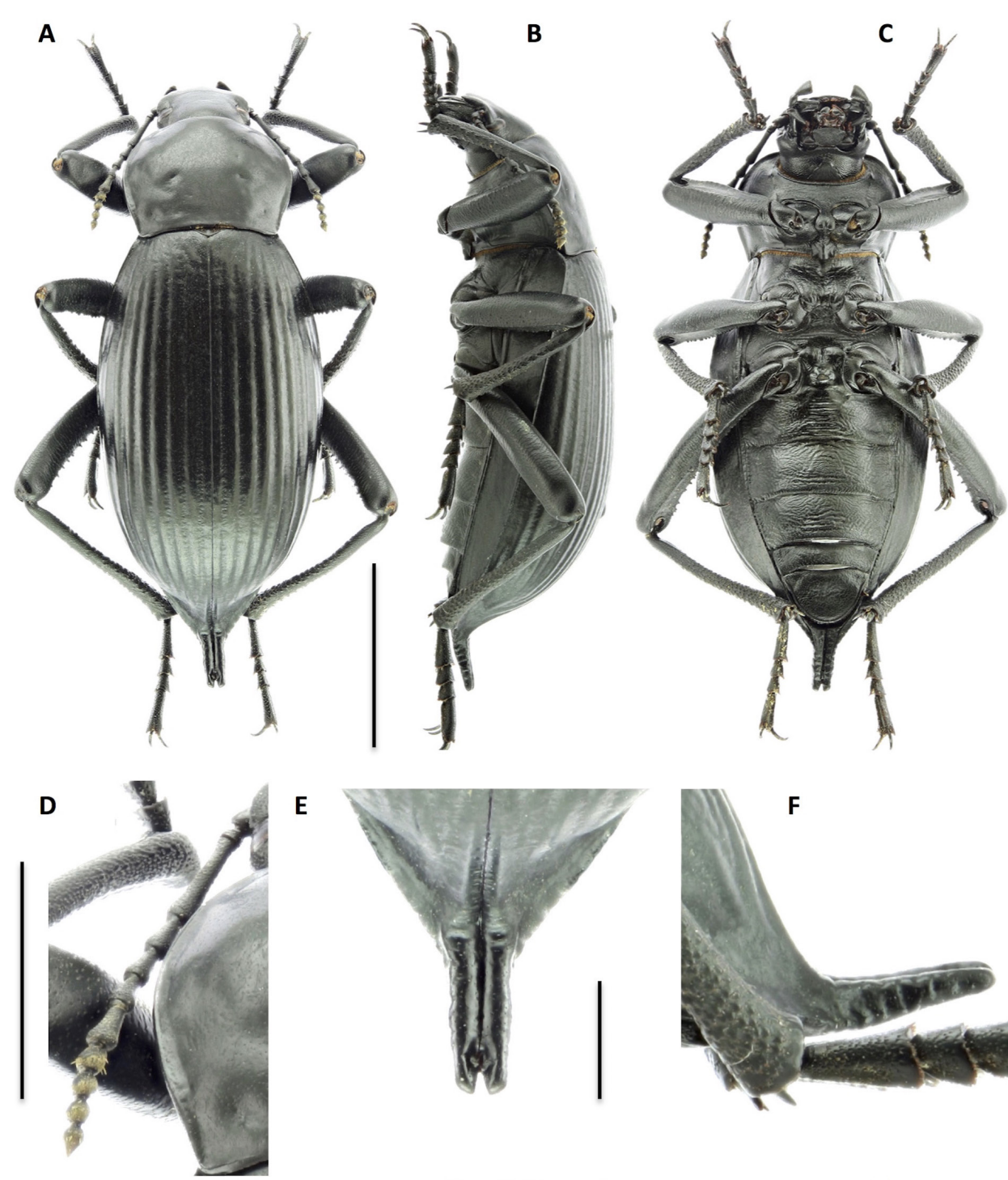

$\mathbf{E}$
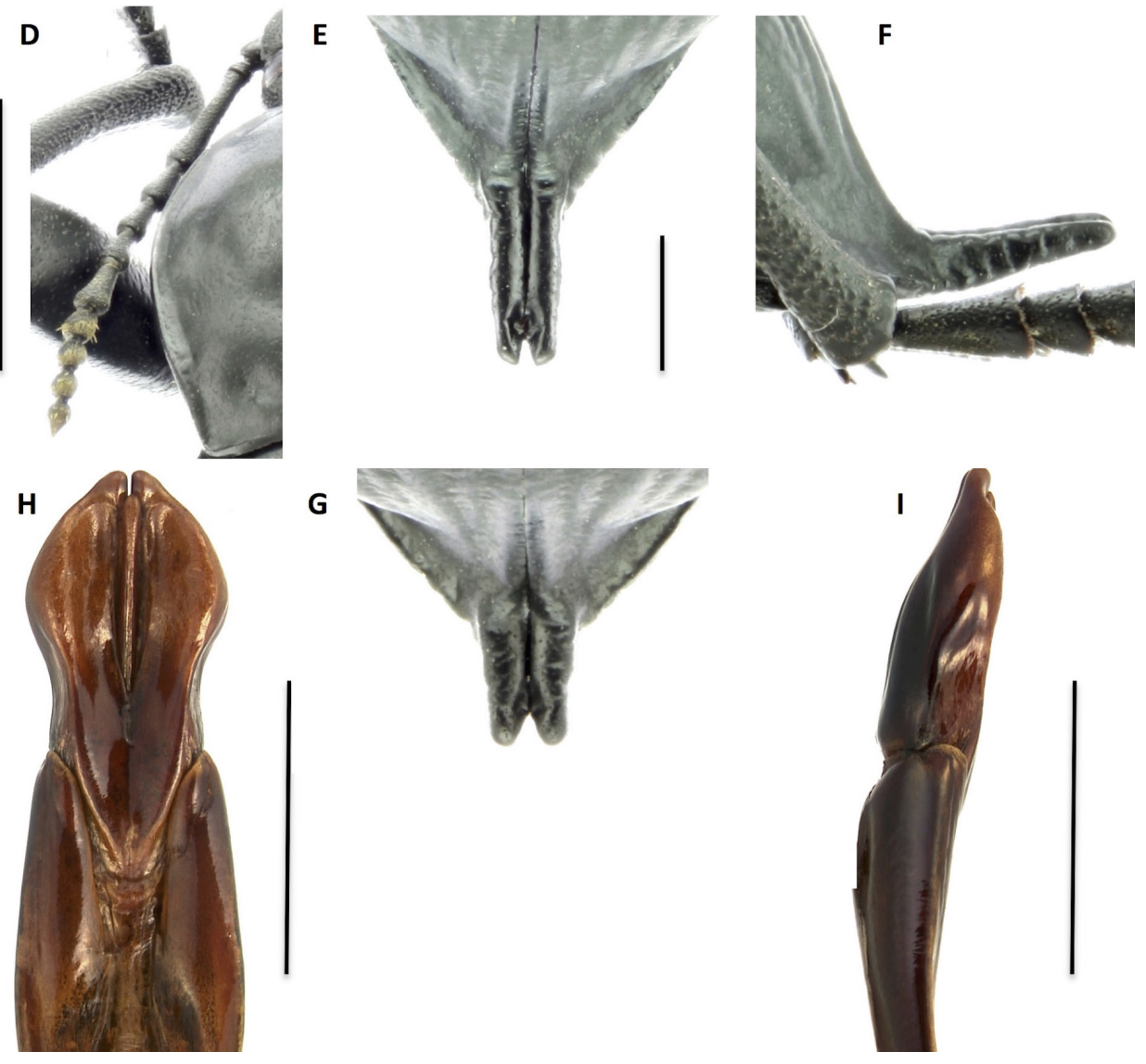

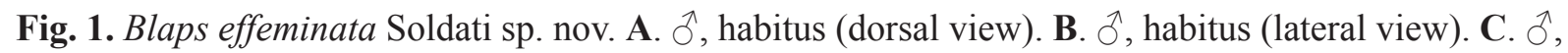
habitus (ventral view). D. $\hat{\jmath}$, left antenna (dorsal view). E. $\hat{\jmath}$, mucro (dorsal view). F. $\hat{\jmath}$, mucro (lateral view). G. $\rho$, mucro (dorsal view). H. $\widehat{\partial}$, aedeagus (ventral view). I. $\hat{\partial}$, aedeagus (lateral view). Scale bars: $\mathrm{A}-\mathrm{C}=10 \mathrm{~mm} ; \mathrm{D}=5 \mathrm{~mm} ; \mathrm{E}-\mathrm{G}=2 \mathrm{~mm} ; \mathrm{H}-\mathrm{I}=3 \mathrm{~mm}$. 
transversely wrinkled ribs, which end in acute angular gap (Fig. 1E). In lateral view, mucro narrow, elongated, progressively narrowed to apex (Fig. 1F) and often bent upwards. Below, mucro grooveshaped, with external edges blurred and bottom transversally wrinkled.

АвDомEN. Ventrites heavily wrinkled-punctate; anal ventrite finely and densely punctate, transversally impressed on disc, external rim complete and fine.

LEGS. Long and slender. Protibiae with internal face sinuous, external one straight in males; similar but less pronounced in females. Outer and posterior face of protibiae and posterior face of mesotibiae superficially grooved. Mesotibiae almost straight. Tarsi long, slender.

SEXUAL DIMORPHISM. In males, no tuft of bristles between ventrites 1 and 2 , and presence of light callosity near base of intercoxal process of ventrite 1 . This callosity reduced to short transverse strip, with some longitudinal and oblique folds on front side, and coarse transversal wrinkles behind. In lateral view posterior declivity of elytra steeper in females. Mucro longer in males $(3.5-4.0 \mathrm{~mm})$ than in females $(2.0$ $2.5 \mathrm{~mm}$ ) (Fig. 1E, G). In males, rear edges of median and especially hind tibiae strongly denticulated. In males, metatibiae straight and flat on inner face; less pronounced in females.

Aedeagus. Parameres widely open, subcordiform, on sternal face (Fig. 1H) with apex triangular. In lateral view (Fig. 1I), parameres very thick and parallel, then abruptly narrowed at apex.

\section{Bionomics}

Most known specimens were collected in antique ruins between April and October.

\section{Distribution}

Libya. This species appears to be endemic to the eastern part of Libya (formerly known as Cyrenaica).

\section{Remarks}

This species belongs to the Blaps gigas species group (sensu Condamine et al. 2011). It is morphologically close to Blaps polychresta Forskål, 1775 from Egypt, from which it differs by: (i) its stronger elytral costulation, especially on the disc; (ii) the absence of the abdominal hair tuft in males (between ventrites 1 and 2); (iii) in males, the presence of a very reduced abdominal callosity located near the base of the intercoxal process of ventrite 1 .

In Eastern Libya, Blaps effeminata sp. nov. can also be confounded with other species of Blaps with costulate elytra, namely B. bifurcata Solier, 1848, B. doderoi Schuster, 1922, B. nitens laportei Ardoin, 1973, B. rhumeri Seidlitz, 1893, B. sulcifera Seidlitz, 1893 and B. wiedemannii Solier, 1848. In Blaps bifurcata, $B$. nitens laportei, $B$. rhumeri and $B$. sulcifera, the mentum is longitudinaly impressed in the middle, with the front edge emarginated. In Blaps doderoi and $B$. wiedemannii, the antennae are shorter (reaching only $3 / 4$ of pronotal length when directed backwards), the abdominal ventrites are much less densely punctuated, the mucro is shorter and much less narrow, the male abdominal callosity is high and rearward, and males exhibit a yellow hair tuft between ventrites 1 and 2 .

$$
\begin{aligned}
& \text { Blaps intermedia Soldati sp. nov. } \\
& \text { urn:lsid:zoobank.org:act:EC3407F9-8A76-4296-AEC5-DFDA9F06CDE1 }
\end{aligned}
$$

Fig. 2A-I

\section{Etymology}

The name of this species refers to the fact that it looks like a morphological intermediary between Blaps appendiculata Motschulsky, 1851 and B. debdouensis Obenberger, 1914. 


\section{Material examined}

Holotype

MOROCCO: đ, “4.IV.1996, Arhbalou, Moyen Atlas, Maroc, P. Jolivet leg. / Museum Paris coll. P. Ardoin 1978 / Blaps ssp. intermedia m. Soldati det. 1996 / Blaps intermedia m. n. sp., L. Soldati 2015, HOLOTYPE" (MNHN).

\section{Paratypes}

MOROCCO: 1 đૈ, "Marocco, Moyen Atlas 6.04.1958 Leg. L. Kocher / Coll. N. Skopin / appendiculata Motsch. 1975 N. Skopin det. / Blaps appendiculata canalicauda subsp. n. / Blaps emondi intermedia

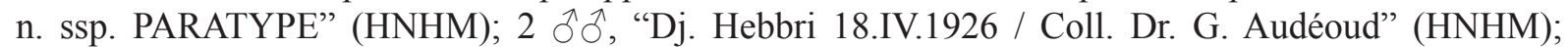

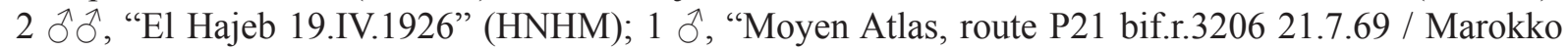

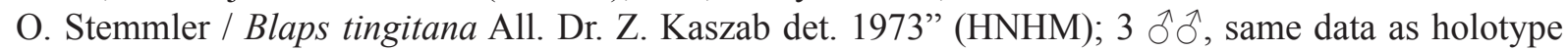

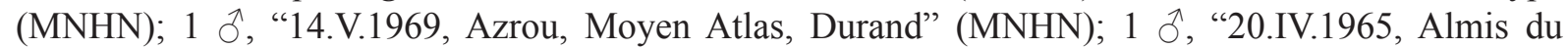
Guigou p. Boulemane, Moyen Atlas, P. Jolivet” (MHNH); 1 ð, “Azrou” (MNHN); 1 ภ, “20.IV.1965, Boulemane, Moyen Atlas, P. Jolivet" (MNHN); 1 đิ, "29.V.1968, 1800 m, Djebel Hebri, Moyen Atlas, Maroc, D. Seiler" (MNHN); 1 ô, "Moyen Atlas, 1960 m, Djebel Hebri, Maroc, 30.IV.1970" (MNHN);

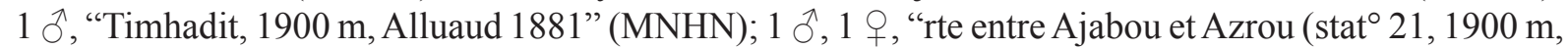

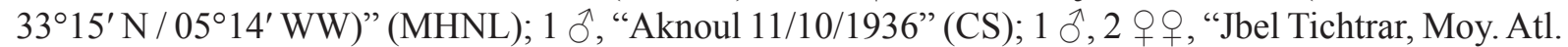
6.1973, Maroc, H. Fongond” (CS); 1 đ, "Tizi Abekhnanes, Jbel Tichtrar, Maroc Moy. Atl. 27.VI.1973,

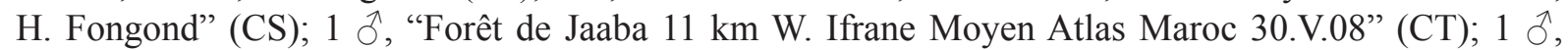
"Maroc m 2000, Moyen Atlas, Aguelmame Sidi Ali, 20.VI.1998, P. Leo" (CMF); 1 q, "Aguelm. Sidi Ali,Moy. Alt., Maroc, 6.IV.1980, H. Fongond" (CMF).

Other material (50 specimens, MNHN)

MOROCCO: Aknoul, Almis du Guigou, Azerzou (SE of Khenifra) (MNHN); Azrou, Arhbalou-nSerdane, Bekrite, $1950 \mathrm{~m}$ (Middle Atlas) (MNHN); Berkane (MNHN); Dayet Ifrah (MNHN); El Hadjeb (MNHN); Ifrane (MNHN); Zaouïa de l'Oued Ifrane (MNHN); Djebel Hebri (MNHN); Guercif (MNHN); Mechrâ Safsaf (near Berkane) (MNHN); Taza (MNHN); Tendrara (MNHN); Timhadit, Zad, $2100 \mathrm{~m}(\mathrm{MNHN})$.

\section{Description}

Length: 32.0-42.0 mm; width: 12.0-16.0 mm. Dull black. Oval-oblong, elongated (Fig. 2A-C). Upper surface covered with very fine and sparse punctures, progressively denser from elytra to head.

HEAD. Clypeus arcuately emarginate, with lateral angles protruding frontwards, clypeo-labial membrane not visible. Clypeo-frontal suture reduced to thin, superficially engraved glossy line. Middle of frons (disc) with faint, generally obliterated, transverse depression. Mentum transverse, punctate and slightly impressed in middle of anterior edge. Gula microshagreened, dull. Labium triangularly emarginated in middle of front edge.

Antennae. Medium size, reaching at most $3 / 4$ of pronotal length when directed backwards (Fig. 2D).

Pronotum. Broadest in its middle, sides distinctly sinuated before posterior angles and arcuatly narrowed frontwards. Anterior angles rounded. Posterior angles sub-right and blunt. External rim fine, complete on lateral margins, but obliterated in middle of front edge and base. Disc convex. Punctuation fine, uniform. Carina of pronotum anterior foramen thick and neck-shaped below. Episternum of prosternum shallowly wrinkled near coxae and obliterate toward margins. Prosternal apophysis vertically bent just behind anterior coxae, then very slightly denticulate in middle at apex.

ELYTRA. Ovoid, broadest around its middle, flat on disc. Upper surface leathery, covered with extremely fine and sparse punctures. Pseudopleural carina only visible from above because of tranversal convexity 

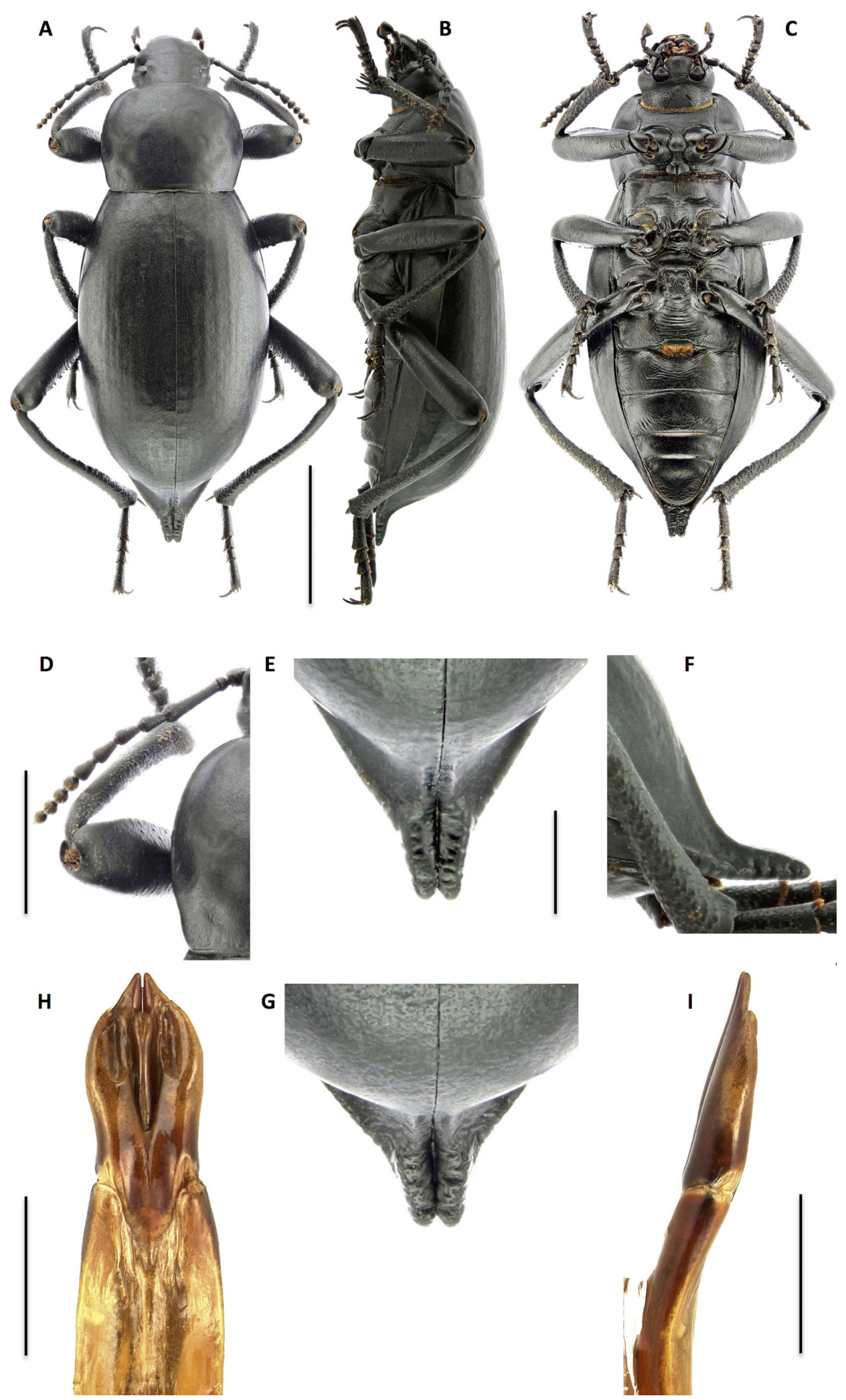

Fig. 2. Blaps intermedia Soldati sp. nov. A. $\hat{\jmath}$, habitus (dorsal view). B. $\hat{\jmath}$, habitus (lateral view). C. $\hat{\jmath}$,

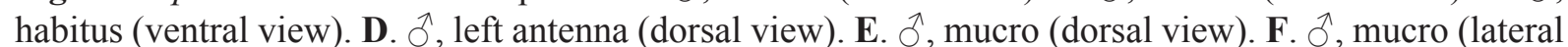
view). G., , mucro (dorsal view). H. $\widehat{\partial}$, aedeagus (ventral view). I. $\hat{\partial}$. aedeagus (lateral view). Scale bars: $\mathrm{A}-\mathrm{C}=10 \mathrm{~mm} ; \mathrm{D}=5 \mathrm{~mm} ; \mathrm{E}-\mathrm{I}=2 \mathrm{~mm}$. 
of elytra. Caudal extension at apex of elytra (mucro) measuring between 1.5 and $3.5 \mathrm{~mm}$. Seen from above, mucro triangularly narrowed; deep suture flanked by two thick, coarsely transversely wrinkled ribs, converging toward apex, which ends in acute angular gap (Fig. 2E). In lateral view, mucro regularly narrowed up to apex, with lower face sub-horizontal (Fig. 2F); below, regularly but not deeply excavated, with sharp external edges and bottom transversally wrinkled.

ABDOMEN. Ventrites wrinkled-punctate; anal ventrite finely punctate, denser along external rim, external rim complete and fine.

LEGS. Mesotibiae curved. Inner face of pro-and mesotibiae superficially grooved.

SeXual Dimorphism. Yellow tuft of bristles between ventrites 1 and 2, and strong callosity between middle and front edge of intercoxal process of ventrite 1. Callosity directed backwards, bifid on top (when not eroded), with some longitudinal and oblique folds on front side, and coarse, transversal wrinkles hindwards. Pseudopleural carina of elytra only visible on anterior half in males, visible on anterior third in females. In lateral view, posterior declivity of elytra steep in males and subvertical in females. Mucro longer in males $(2.0-3.5 \mathrm{~mm})$ than in females $(1.5-2.0 \mathrm{~mm})$ (Fig. 2E, G). Male protibiae slightly flexuous; straight in females. In males, rear edges of median and especially hind tibiae strongly denticulate. Male metatibiae flexuous and shallowly emarginated on inner face; female metatibiae straight and simple.

Aedeagus. Parameres open on sternal face (Fig. 2H), with apex acuminate. In lateral view (Fig. 2I), parameres thick and convex at base, then narrowed almost in straight line up to apex.

\section{Bionomics}

The examined material was collected between April and October.

\section{Distribution}

Morocco: Middle Atlas mountain range and further north, up to the surroundings of Taza and Aknoul.

\section{Remarks}

This species belongs to the Blaps emondi species group (sensu Condamine et al. 2011). Blaps intermedia sp. nov. is morphologically very close to $B$. debdouensis, and the aedeagus is the most reliable character to the two species: in $B$. intermedia sp. nov. the parameres are more extended laterally and appear inflated, whereas they are parallel and gutter-shaped in B. debdouensis. However, it is worth underlining that the aedeagus is often distorted by dehydration because of the very thin lateral tegument of the parameres. In the case of isolated females, the geographic distribution is a good criterion to distinguish females of Blaps intermedia sp. nov. from females of B. debdouensis.

\section{Blaps maldesi Soldati sp. nov. urn:1sid:zoobank.org:act:ECAD95F0-9469-4AA3-824D-960F20F3DD15}

Fig. 3A-I

\section{Etymology}

This species is named in honor of Jean-Michel Maldes, friend and colleague, entomologist at the CIRAD, specialist in Asilidae (Diptera), who discovered this new species of Blaps while prospecting in the Aures mountain range.

\section{Material examined}

\section{Holotype}

ALGERIA: Ō, “Algérie, M ${ }^{\text {if }}$ Aurès, S'Gag, 1900 m, 19.VI.1981 / ALGERIE J. M. MALDES / Blaps maldesi m. n. sp., L. Soldati 2015, HOLOTYPE” (MNHN). 
SOLDATI L. et al., Blaps systematics and taxonomy

\begin{abstract}
Allotype
ALGERIA: ㅇ, "S' Gag, 2000 m, Ras Gueddelane, Mif des Aurès, 18.VI.1981 / ALGERIE J. M. MALDES

/ Blaps maldesi m. n. sp., L. Soldati 2015” (MNHN).

Paratype

ALGERIA: 1 đ̊, "Sgag (Aurès) / Blaps maldesi m. n. sp., L. Soldati 2015, PARATYPE” (CS).

\section{Description}

Length: 29.0-35.0 mm; width: 10.0-15.0 mm. Dull to semi-gloss black. Oval-oblong (Fig. 3A-C). Upper surface covered with very fine and sparse punctures, denser on head and pronotum.

Head. Clypeus arcuately emarginated, with lateral angles right and protruding frontwards, leaving clypeo-labial membrane partially visible. Clypeo-frontal suture reduced to thin, superficially engraved gloss line. Middle of frons (disc) with faint transverse depression. Mentum transverse, punctate and slightly impressed in middle of anterior edge. Gula microshagreened, matte. Labium deeply notched in middle of front edge.
\end{abstract}

AnTENNAE. Medium size, not reaching pronotal base when directed backwards (Fig. 3D).

Pronotum. Broadest in its middle, sides narrowed almost in straight line posteriorly, sinuated before posterior angles and arcuately narrowed toward front. Anterior angles rounded. Posterior angles obtuse and blunt. External rim fine, complete on lateral margins, but briefly obliterated in middle of front edge and base. Disc quite convex. Punctation fine, uniform. Carina of anterior foramen of pronotum thick and neck-shaped below. Episternum of prosternum wrinkled near coxae and obliterate toward sides. Prosternal apophysis vertically bent just behind anterior coxae, then flat and non-protruding posteriorly.

Elytra. Ovoid, broadest around its middle, flat on disc. Upper surface leathery and covered with extremely fine and sparse punctures. Pseudopleural carina only visible on anterior half from above because of transversal convexity of elytra. Caudal extension at apex of elytra (mucro) measuring less than $2.0 \mathrm{~mm}$. Deep suture of mucro flanked by two thick, coarsely transversely wrinkled ribs, converging toward apex, apex ends in narrow apical gap (Fig. 3E). In lateral view, mucro regularly sloping up to apex (Fig. 3F). Below, mucro regularly excavated, with sharp external edges and bottom transversally wrinkled.

AвDOMEN. Ventrites wrinkled-punctate; anal ventrite densely punctate, especially along external rim, external rim complete and quite thick. In one case (paratype), external rim of anal ventrite shortly interrupted in middle of apex.

Legs. Protibiae long and flexuous, especially in males. Mesotibiae curved. Inner face of pro- and mesotibiae widely grooved. Tarsi elongated; claws long. Hind tarsi approximately as long as one half of length of corresponding tibiae.

SeXual dimorphism. Yellow tuft of bristles between ventrites 1 and 2, and a callosity in middle of intercoxal process of ventrite 1. Callosity directed backwards, with some oblique folds on front side. Elytra slightly larger than pronotum in males. In lateral view, posterior declivity of elytra steep in males and subvertical in females. Mucro longer in males $(1.5-2.0 \mathrm{~mm})$ than in females $(0.5 \mathrm{~mm})$ (Fig. 3E, G). Seem from above, mucro triangularly narrowed in males and acuminate in females. Rear edges of median and especially hind tibiae strongly denticulate in males. Male metatibiae flexuous and shallowly emarginated on inner face; female metatibiae straight and simple. 

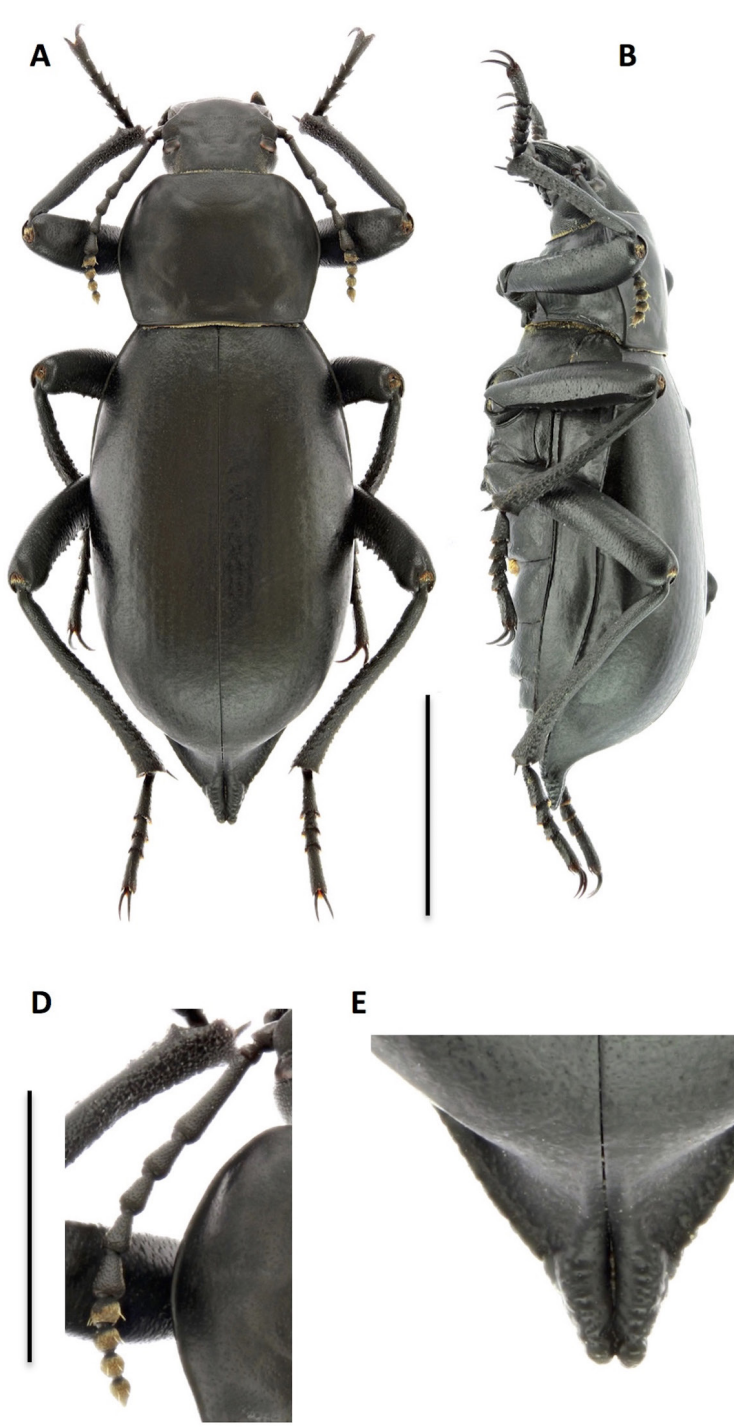

H

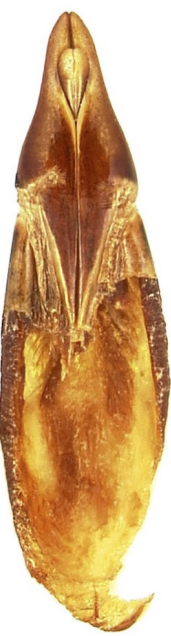
$\mathbf{E}$

G

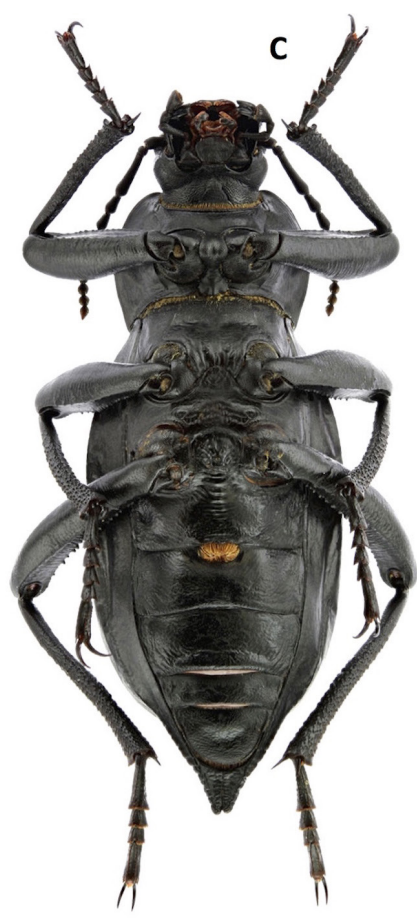

$\mathbf{F}$
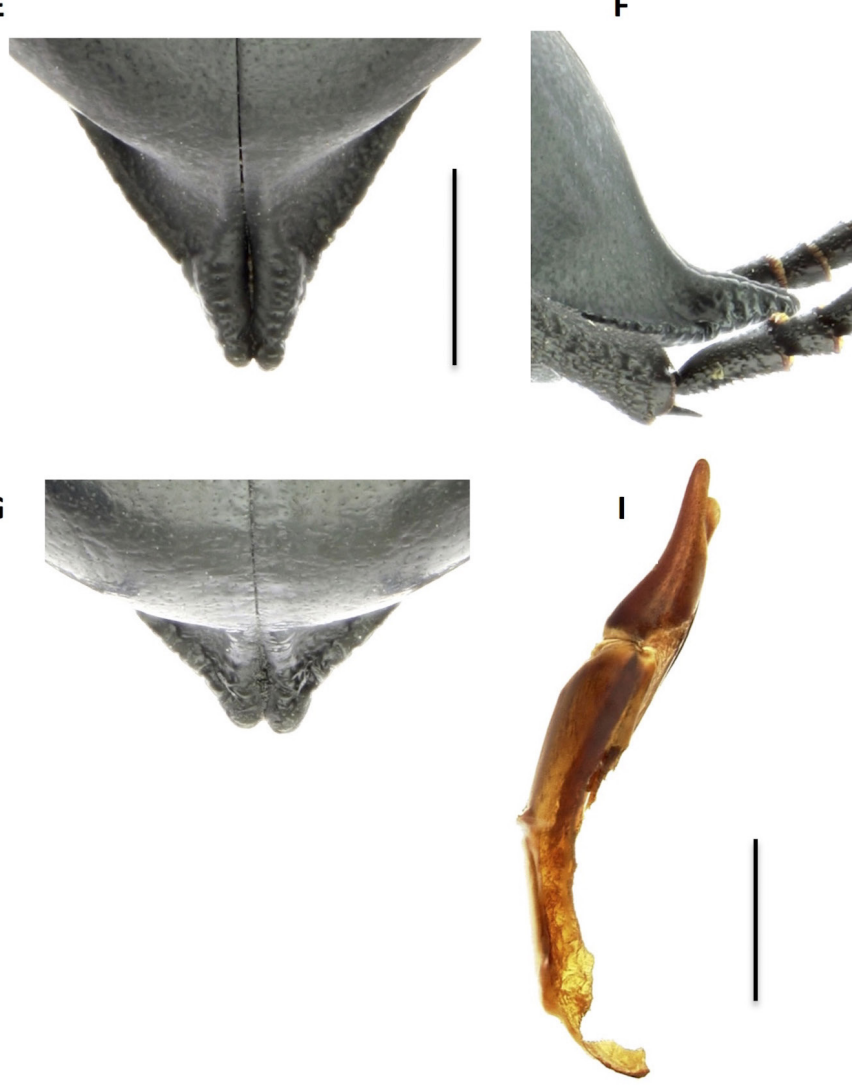

Fig. 3. Blaps maldesi Soldati sp. nov. A. $\widehat{\partial}$, habitus (dorsal view). B. $\widehat{\partial}$, habitus (lateral view). C. $\widehat{\partial}$,

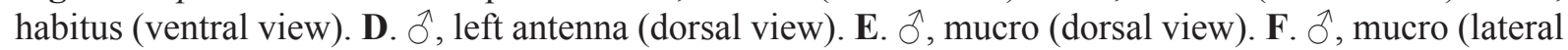
view). G. + , mucro (dorsal view). H. $\widehat{\partial}$, aedeagus (ventral view). I. $\hat{\partial}$, aedeagus (lateral view). Scale bars: $\mathrm{A}-\mathrm{C}=10 \mathrm{~mm}$; $\mathrm{D}=5 \mathrm{~mm} ; \mathrm{E}-\mathrm{G}=2 \mathrm{~mm} ; \mathrm{H}-\mathrm{I}=1 \mathrm{~mm}$. 
Aedeagus. Parameres bottleneck-shaped on sternal face (Fig. 3H), with apex acuminate. In lateral view (Fig. 3I), parameres thick and convex at base, then narrowed almost in a straight line up to apex.

\section{Bionomics}

The three known specimens were taken in the cedar forest of S' Gag (Algeria).

\section{Distribution}

Algeria. This species is currently known only from the type locality of S'Gag in the Aurès region.

\section{Remarks}

This species belongs to the Blaps emondi species group (sensu Condamine et al. 2011). It is morphologically most similar to $B$. teocchii sp. nov. from Tunisia. Blaps maldesi sp. nov. is most clearly separated from $B$. teocchii sp. nov. by having shorter antennae and tarsi, a wider pronotum and by the presence of a tuft of yellow bristles between abdominal ventrites 1 and 2. Until now, these two species have passed unnoticed in the collections because they superficially look like small specimens of other species of the emondi group, especially when the specimens are prepared in the old-fashioned way, with the legs tucked under the body. Compared to other species in the emondi group, these two species are characterized by the following combination of characters: slender legs; long and flexuous fore-tibiae, with inferior face distinctly grooved; tarsi long; and bottleneck-shaped parameres of aedeagus.

Blaps nitiduloides Soldati sp. nov. urn:1sid:zoobank.org:act:FF763E9B-8763-45D7-B809-2030C9802FAA

Fig. 4A-I

\section{Etymology}

The name of this species refers to its resemblance to Blaps emondi var. nitidula Solier, 1848.

\section{Material examined}

\section{Holotype}

TUNISIA: đ̃, "27.IV.1964, Maktar, TUNISIE, Besnard réc. / MUSEUM PARIS COLL. P. ARDOIN 1978 / Blaps binominata Esc. = caudigera Allard P. ARDOIN DET. 1977 / Blaps nitiduloides m. n. sp. L. Soldati 2015, HOLOTYPE” (MNHN).

\section{Allotype}

TUNISIA: +, "Tunis / MUSEUM PARIS COLL. L. BEDEL 1922 / Blaps nitiduloides m. n. sp. L. Soldati 2015, ALLOTYPE” (MNHN).

\section{Paratypes}

ALGERIA: 1 ô, “Aïn Beida, Constantinois, ALGERIE” (MNHN).

TUNISIA: 1 ภ, 1 \&, “Tunis 9.IX.26 J. Briel” (MNHN); 1 §, "27.IV.1964, Maktar, TUNISIE, Besnard réc." (MNHN); 1 ô, "Carthage, Tunisie, 10.IX.26, Briel" (MNHN); 1 ô, 1 क, "MUSEUM PARIS TUNIS Belvédère A. WEISS 1902" (MNHN); 1 §, "Teboursouk, Tunisie" (MNHN); 1 ô, "Hadger El Aioun (Tunisie) DE VAULOGER" (MNHN); 1 ô, "Sbeitla, De Vauloger" (MNHN); 1 q, "Tunis: Gassa (91 Augos) / Edmondi / Sammlung J. Daniel / Blaps $q$ ? torretassoi Koch i. 1. 1977 N. Skopin det."

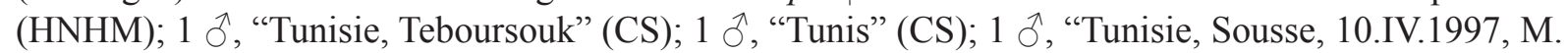
Martinez leg." (CS); 1 †, "27.IV.1964, Maktar, TUNISIE, Besnard réc." (CS); 1 ô, 1 ๆ, "Tunisia NE, Hammam-Lif, 3-4.IV.1999, lgt. M. Kalabza" (CT); 1 †, "Tunisia NW, 20 km N Beja, 19.4.2001, LGT. M. Halada" (CT). 
Other material ( 3 specimens, MNHN)

ALGERIA: Constantine (Khenichela), Mt Tebessa, 1100 m (MNHN).

TUNISIA: Carthago, Radès (MNHN).

\section{Description}

Length: 33.0-42.0 mm; width: 12.5-16.0 mm. Semi-gloss black (Fig. 4A-C). Upper surface covered with extremely fine, sparse and superficial punctures.

HEAD. Covered with fine punctation, more pronounced than on rest of upper body surface. Punctation becomes even denser on clypeus. Clypeus arcuately emarginated, with anterior angles right and protruding frontwards, leaving clypeo-labial membrane partially visible. Clypeo-frontal suture reduced to thin, brilliant line. In middle of frons, just behind eyes, two shallow, circular depressions, sometimes joined by short transverse depression. Mentum transverse, densely and coarsely punctate. Gula microshagreened, matte. Labium deeply notched in middle of front edge.

Antennae (Fig. 4D). Short, barely reaching basal third of pronotum when directed backwards. Antennomeres 4-7 particularly short and thick.

Pronotum. Usually weakly transverse, not wider than long, broadest at or just behind its middle. Disc slightly convex. Sides regularly arcuate, except at posterior angles. Posterior angles obtuse and blunt. Anterior angles rounded. External rim complete on lateral margins, but obliterated in middle of front edge and base. Punctation extremely fine, sometimes barely visible. Carina of anterior foramen of pronotum very thick and neck-shaped. Episternum of prosternum superficially wrinkled. Prosternal apophysis vertically bent just after anterior coxae, then flat and generally non-protruding posteriorly.

ELYTRA. Ovoid, broadest around its middle. Upper surface smooth and covered with extremely fine and sparse punctures; background integument shining. Pseudopleural carina just visible on anterior half from above because of transversal convexity of elytra. Posterior declivity of elytra steep in lateral view. Mucro at apex of elytra measuring between 2.0 and $5.0 \mathrm{~mm}$. Seen from above, deep suture flanked by two thick, coarsely transversely striated ribs, converging in curve toward apex, apex ending in deep and narrow apical gap (Fig. 4E). In lateral view, mucro thick on $3 / 4$ of its length, then abruptly sloping toward apex (Fig. 4F). Basin-shaped below, with bottom coarsely striated transversely.

АвDOMEn. Ventrites wrinkled; anal ventrite punctate, with light depression on disc, external rim complete.

LeGs. Quite short and stout. Protibiae slightly curved. Tarsi short.

SeXUAL Dimorphism. No tuft of bristles between ventrites 1 and 2, but strong callosity present in middle of intercoxal process of ventrite 1 in males. Mucro longer in males $(2.5-5.0 \mathrm{~mm})$ than in females $(2.0-$ $2.2 \mathrm{~mm}$ ) (Fig. 4E, G). Male mesotibiae curved, slightly grooved on upper face. Male posterior tibiae flexuous and shallowly emarginated in middle of inner side, straight and simple in females.

Aedeagus. On sternal face (Fig. 4H), parameres open, subparallel for $4 / 5$ of their length, then triangularly narrowed at apex. In lateral view (Fig. 4I), parameres first subparallel for $\% / 10$ of their length, then obliquely truncated and end in a point.

\section{Bionomics}

The examined material was collected between April and September. 

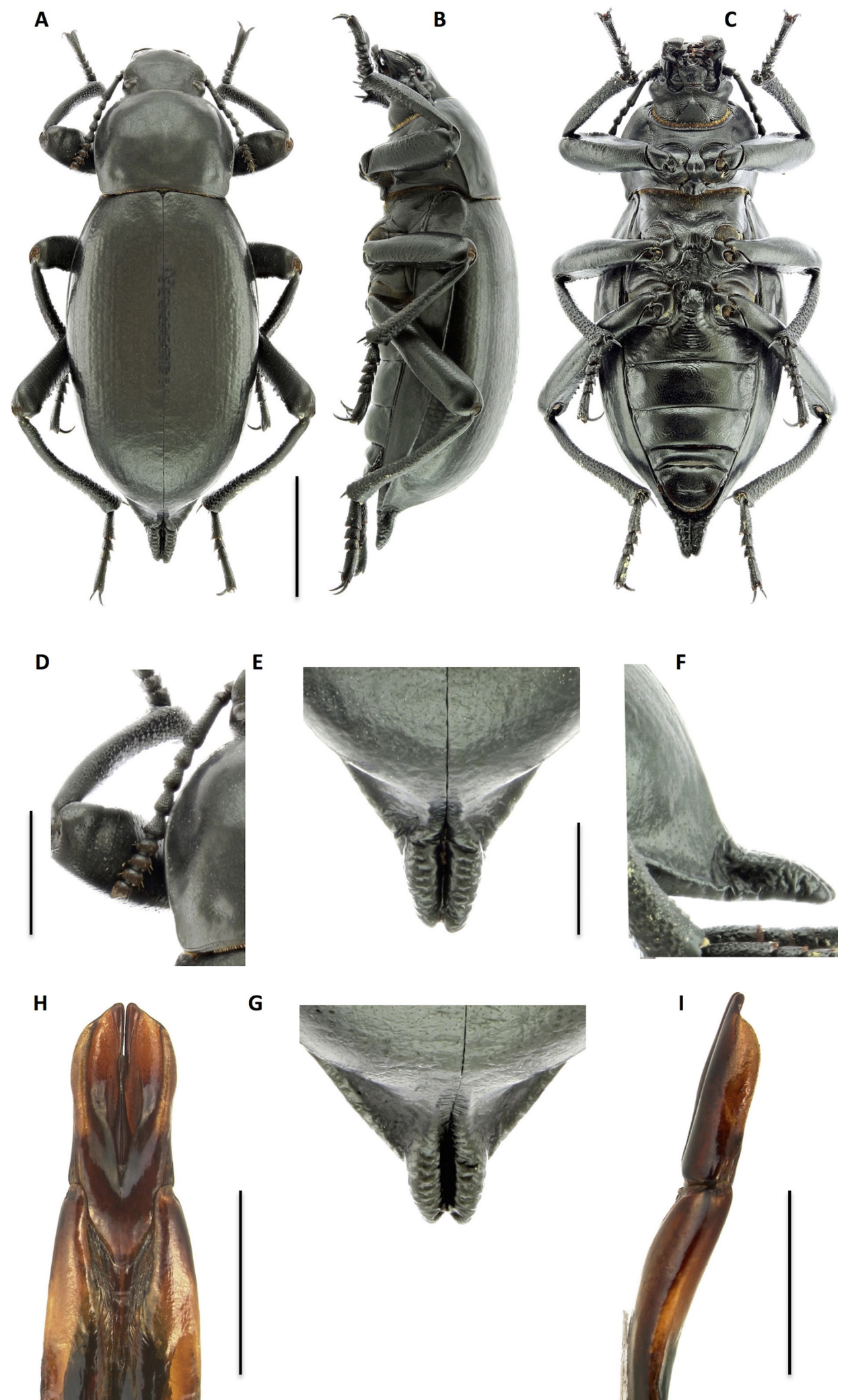

G
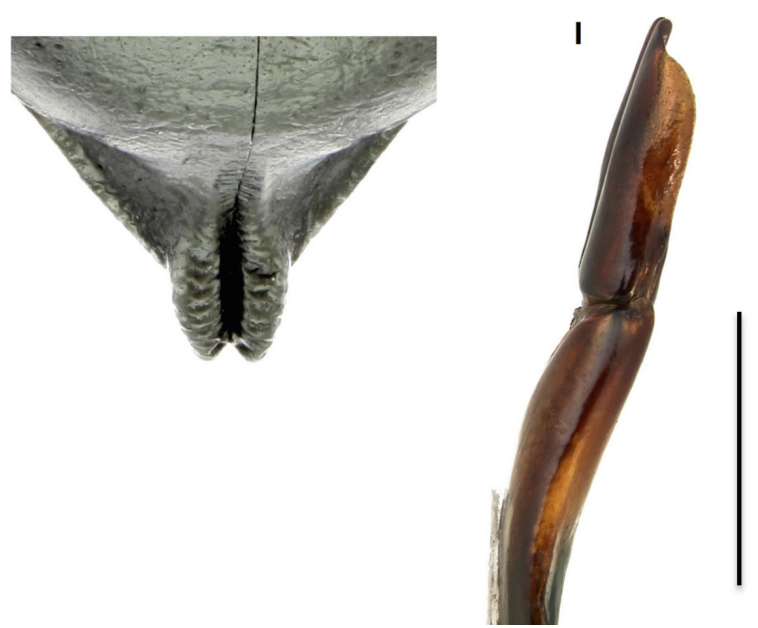

Fig. 4. Blaps nitiduloides Soldati sp. nov. A. $\hat{\partial}$, habitus (dorsal view). B. $\widehat{\partial}$, habitus (lateral view). C. $\widehat{\partial}$, habitus (ventral view). D. $\hat{\jmath}$, left antenna (dorsal view). E. $\partial^{\lambda}$, mucro (dorsal view). F. $\partial^{\lambda}$, mucro (lateral view). G. + , mucro (dorsal view). H. $\widehat{\partial}$, aedeagus (ventral view). I. $\hat{\partial}$, aedeagus (lateral view). Scale bars: $\mathrm{A}-\mathrm{C}=10 \mathrm{~mm} ; \mathrm{D}=5 \mathrm{~mm}$; $\mathrm{E}-\mathrm{I}=2 \mathrm{~mm}$. 


\section{Distribution}

Algeria and Tunisia. This species is currently only known from Tunisia and the Constantine region of Algeria.

\section{Remarks}

This species belongs to the Blaps emondi species group (sensu Condamine et al. 2011). It is morphologically related to B. emondi Solier, 1848 and B. binominata Escalera, 1914. In B. binominata the characteristic mucro is very broad and parallel, with a strong apical gap at a right angle. The male of $B$. emondi exhibits a tuft of yellow bristles between ventrites 1 and 2, and the abdominal callosity is located near the front edge of the intercoxal process of ventrite 1. It is also worth highlighting that Blaps nitiduloides sp. nov. is not found in sympatry with either $B$. binominata or $B$. emondi; the latter occurs in central and western Algeria, north of the 'Hauts Plateaux', and northeastern Morocco, whereas the distribution of B. binominata extends from the Oran region to the northeast of Morocco and the Spanish enclave of Melilla.

$$
\begin{aligned}
& \text { Blaps teocchii Soldati sp. nov. } \\
& \text { urn:1sid:zoobank.org:act:BBAE8764-F336-4941-9657-009531E258BC }
\end{aligned}
$$

Fig. 5A-I

\section{Etymology}

This species is named in honour of Pierre Teocchi, cerambycid specialist, to whom one of us (L. Soldati) owes having become an entomologist.

\section{Material examined}

Holotype

TUNISIA: Ō, “Zaghouan, 20-22.V.1995, M. Ouda leg. / Blaps teocchii m. n. sp. L. Soldati 2015, HOLOTYPE" (MNHN).

\section{Allotype}

TUNISIA: , , same data as holotype (MNHN).

\section{Paratypes}

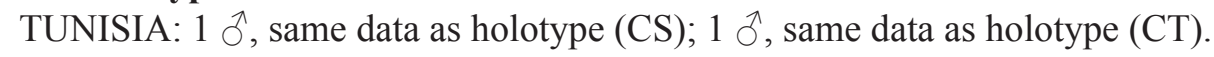

\section{Description}

Length: 31.0-33.0 mm; width: 11.0-13.0 mm. Semi-gloss black. Oval-oblong (Fig. 5A-C). Upper surface covered with very fine, sparse and superficial punctures, denser on head and pronotum.

HEAD. Clypeus arcuately emarginated, with lateral angles right and protruding frontwards, leaving clypeolabial membrane partially visible. Clypeo-frontal suture reduced to thin gloss line. Middle of frons (disc) with faint transverse depression. Mentum transverse, coarsely punctate and slightly impressed in middle of anterior edge. Gula microshagreened, matte. Labium deeply notched in middle of front edge.

ANTENNAE. Slender, barely reaching pronotal base when directed backwards (Fig. 5D).

Pronotum. Broadest in its middle, with sides narrowed almost in straight line posteriorly and arcuately towards front. Anterior angles rounded. Posterior angles obtuse and blunt. External rim fine, complete on lateral margins but obliterated in middle of front edge and base. Disc slightly convex. Punctation fine, uniform, as on head. Carina of anterior foramen of pronotum thick and neck-shaped below. Episternum 

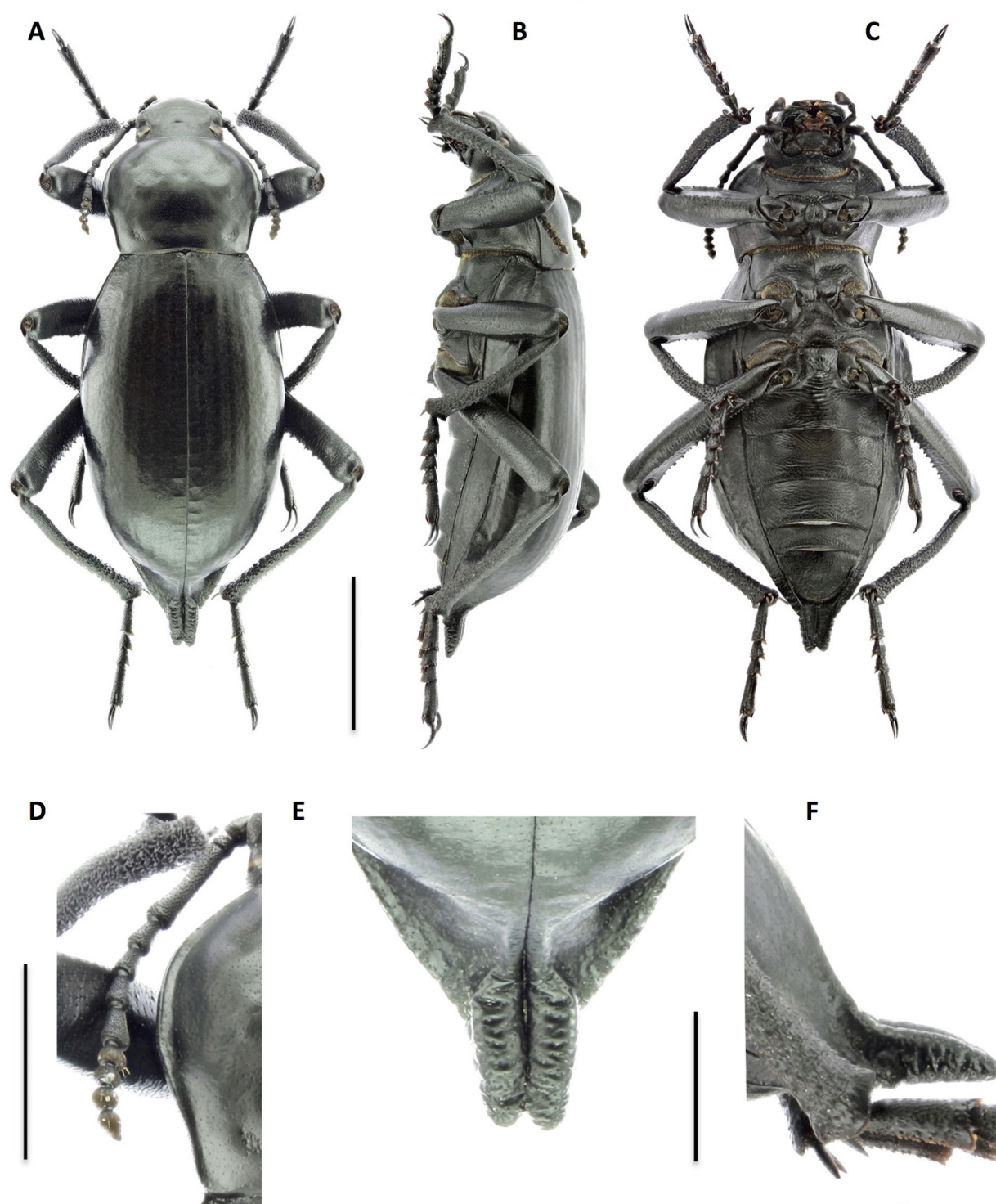

E
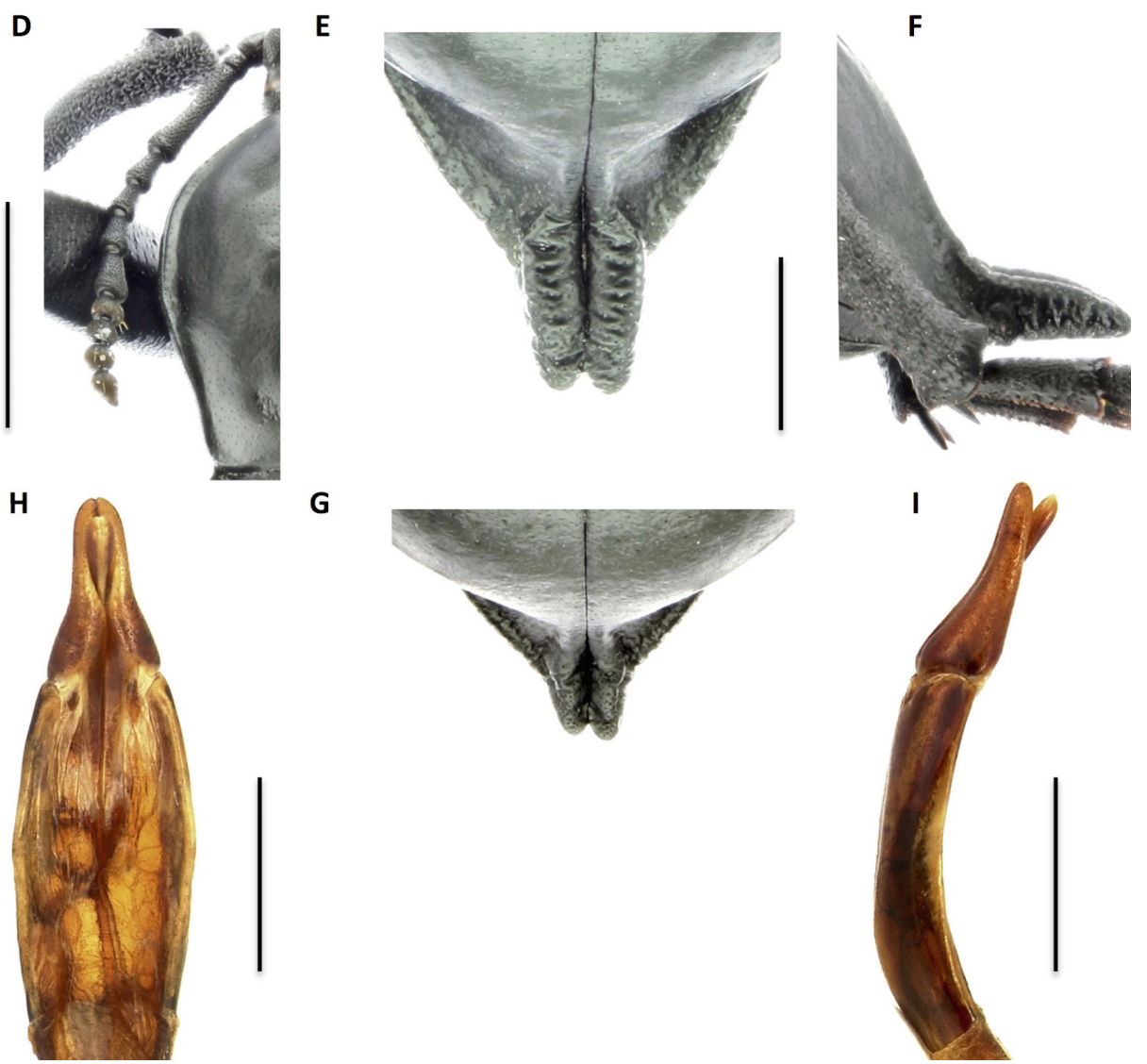

G
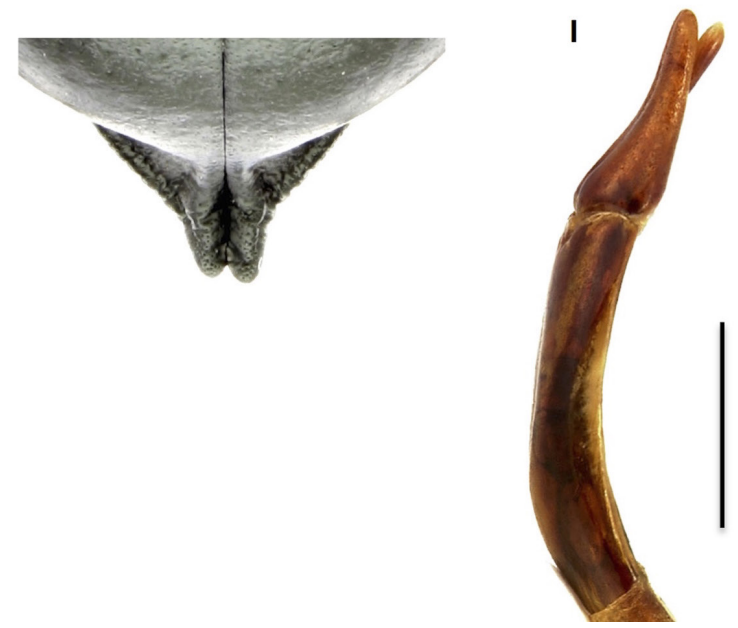

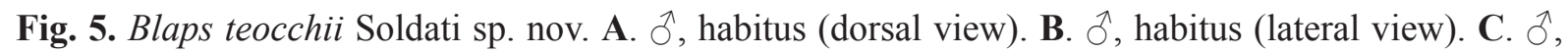
habitus (ventral view). D. $\partial^{\lambda}$, left antenna (dorsal view). E. $\hat{\jmath}$, mucro (dorsal view). F. 0 , mucro (lateral

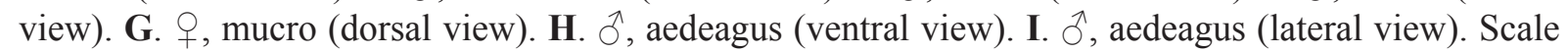
bars: $\mathrm{A}-\mathrm{C}=10 \mathrm{~mm} ; \mathrm{D}=5 \mathrm{~mm}$; $-\mathrm{G}=2 \mathrm{~mm} ; \mathrm{H}-\mathrm{I}=1.5 \mathrm{~mm}$. 
of prosternum superficially wrinkled. Prosternal apophysis vertically bent just behind anterior coxae, then flat and non-protruding posteriorly.

ElYTRA. Ovoid, broadest around its middle, depressed on disc. Upper surface smooth and covered with very fine and sparse punctures; background integument semi-gloss. Caudal extension at apex of elytra (mucro) measuring between 1.0 and $2.5 \mathrm{~mm}$. Seen from above, mucro almost subparallel; deep suture flanked by two thick, coarsely transversely wrinkled ribs, slightly converging toward apex, apex ending in narrow apical gap (Fig. 5E). In lateral view, mucro regularly sloping up to apex (Fig. 5F). Seen from below, mucro regularly excavated, with sharp external edges and bottom transversally wrinkled.

AвDOMEN. Ventrites wrinkled-punctate; anal ventrite densely punctate, with external rim complete and quite thick.

Legs. Protibiae long and flexuous. Mesotibiae curved. Inner face of pro- and mesotibiae widely grooved. Tarsi elongated and stout; claws long. Hind tarsi as long as $3 / 4$ of length of corresponding tibiae.

SeXual Dimorphism. No yellow tuft of bristles between ventrites 1 and 2, but strong callosity present between middle and anterior ridge of intercoxal process of ventrite 1 and directed backwards, with some oblique folds on front side. Elytra slightly larger than pronotum in males. Pseudopleural carina only visible on anterior half from above in males, or on anterior third in females, because of transversal convexity of elytra. In lateral view, posterior declivity of elytra steeper in females. Mucro longer in males $(2.5 \mathrm{~mm})$ than in females $(1.0 \mathrm{~mm})$ (Fig. 5E, G). Rear edges of median and especially hind tibiae strongly denticulate in males. Male metatibiae flexuous and shallowly emarginated on inner face at middle third; straight and simple in females.

Aedeagus. Parameres bottleneck-shaped on sternal face (Fig. 5H), with apex acuminate. In lateral view (Fig. 5I), parameres thick and convex at base, then narrowed almost in straight line up to apex.

\section{Bionomics}

Unknown.

\section{Distribution}

Tunisia. So far known only from the type locality of Zaghouan in Tunisia.

\section{Remarks}

This species belongs to the Blaps emondi species group (sensu Condamine et al. 2011). It is morphologically very similar to B. maldesi sp. nov. from Tunisia (see above for more information).

\section{Phylogenetics analyses}

Overall, the phylogenetic analyses resulted in a relatively well-supported tree $(70.8 \%$ and $43.3 \%$ of nodes supported by $\mathrm{PP} \geq 0.50$ and 0.95 , respectively; see Fig. 6$)$. Nodal support was usually low $(\mathrm{PP}<0.50)$ for the terminal parts of the tree encompassing taxa for which only morphological information was available (but see also Blaps magica Erichson, 1841 and B. antennalis Allard, 1880).

The monophyly of the tribe Blaptini was recovered with strong support $(\mathrm{PP}=0.96)$. Of particular interest is the fact that the genus Blaps is not monophyletic in our phylogenetic reconstruction, due to the placement of the four other members of the Blaptini tribe. The latter are recovered in a weakly supported clade $(\mathrm{PP}=0.49)$ sister to a large, well-supported clade $(\mathrm{PP}=0.95)$ that encompasses all sampled representatives of the subgenus Blaps belonging to section I. For their part, all sampled members of the subgenus Blaps belonging to section II are recovered in a weakly supported clade $(\mathrm{PP}=0.31$ ), which 

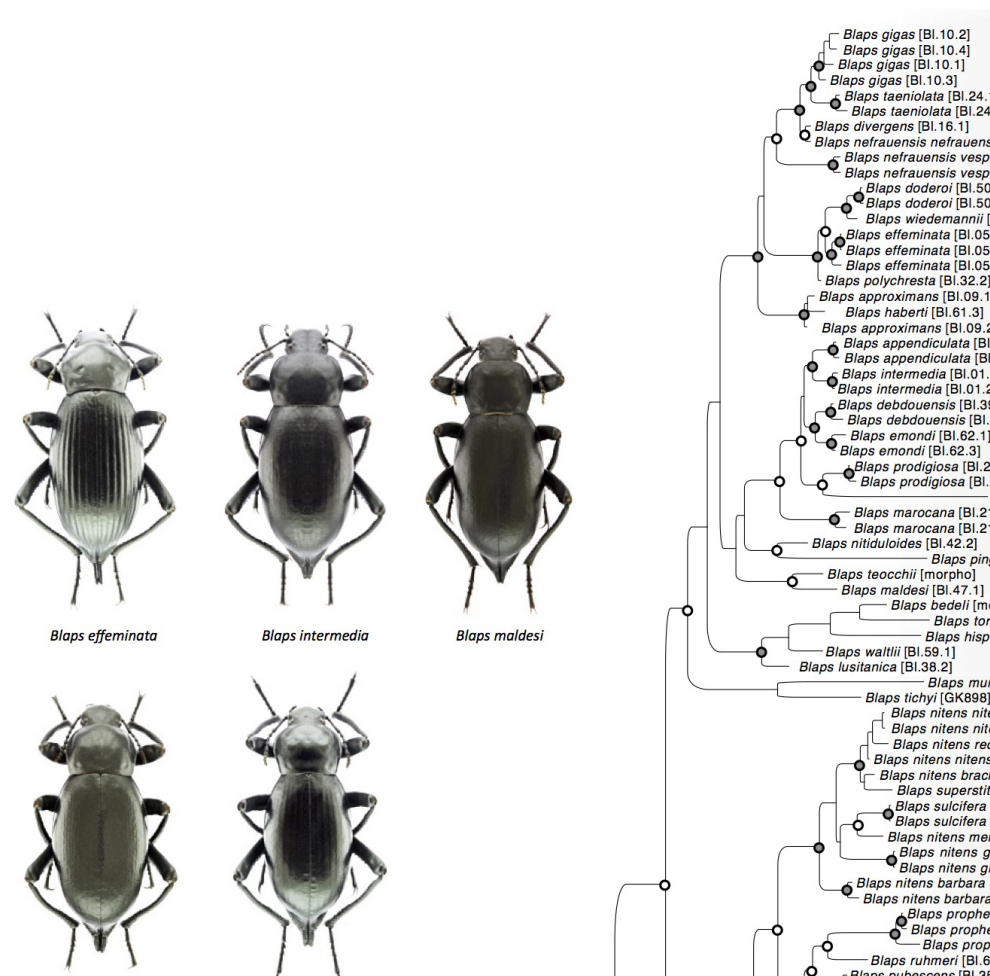

Blaps intermedia
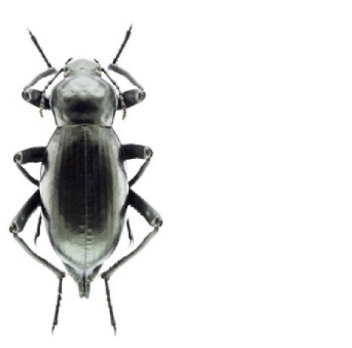

Blaps nitiduloides

$$
\text { Blaps teocchii }
$$

O $P P \geq 0.50$

$O P P \geq 0.95$

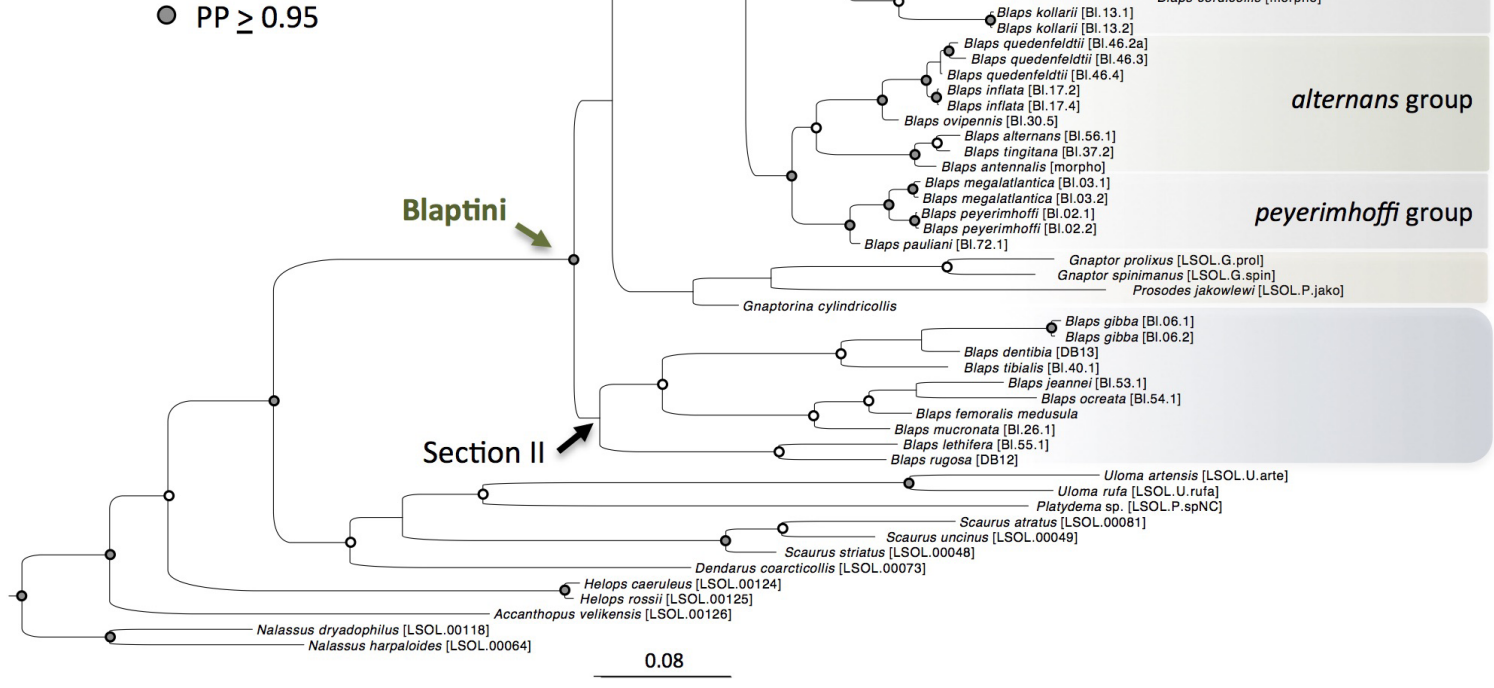

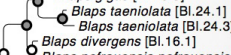

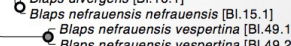

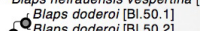

Blaps wiedemannili [B1.60.1]

0 Blaps effeminata [B. 1.05 .2$]$

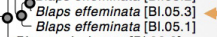

Blaps polychrestat [1.1.32.2.2]
Blaps approximans [B1.09.1]

[ Blaps approximant [B1.09.1]

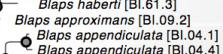

$\left\{\begin{array}{l}\text { Blaps appendiculata [BB.04.4] } \\ \text { Blaps intermedia [BI.01.1] }\end{array}\right.$

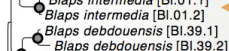

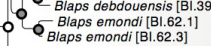

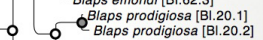

O- Blaps marocana [B.21.1]

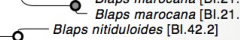

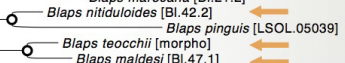

Blaps maldesi i B B.47.11 11.

Blaps torressalai [morphol
Blaps wattii [B.59.1]

Baps lusitanica [B.31.38.2]

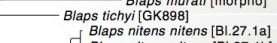

$\left[\begin{array}{l}\text { Blaps nitens nitens [B.2.27.1a] } \\ \text { Blaps nitens nitens }[B .27 .126]\end{array}\right.$

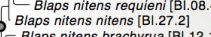
[laps nitens brachyrua [B].12.1]
Blaps superstitiosa supertifitiosa [B1.66.11]

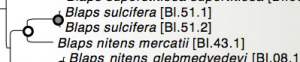

(nitens group)

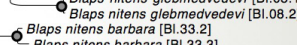

Blaps nitens barbara [B.3.33.3.

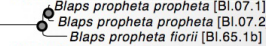

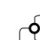

Des ruhmeri [BI.64.11]

$\mathrm{Q}_{\text {Blaps pubescens [ [B1.35.26] }}$
Blaps pubescens [B1.35.1]

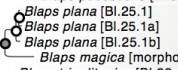

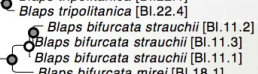

(bifurcata group)

Section I
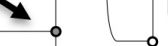

cordicollis group

(/usitanica group)

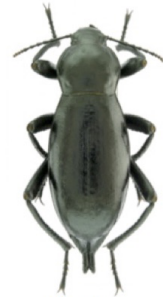

Blaps gigas
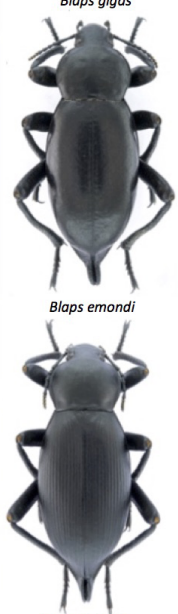

(propheta group)
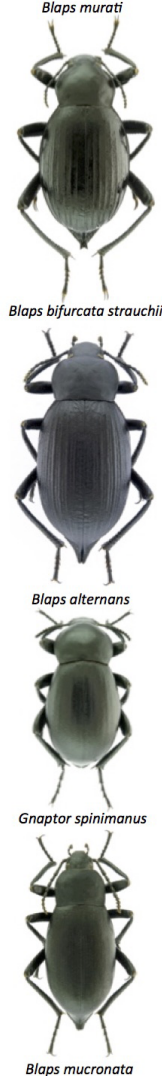

Fig. 6. Bayesian maximum consensus tree resulting from the analysis of the combined molecular and morphological dataset carried out with MrBayes. Support of nodes is indicated using empty circles (for $\mathrm{PP} \geq 0.50$ ) and filled circles for $\mathrm{PP} \geq 0.95$ ). Species groups for Blaps belonging to section I are highlighted using transparent coloured frames. Paraphyletic species groups are highlighted using bracketed names; orange arrows are also used to highlight the placement of the five new species. For illustrative purposes, the habitus of some adults are figured on the right side of the figure; on the left upper side, the habitus of the five new species are also presented (all photographs were taken by L. Soldati). 
is sister to all other sampled Blaptini. Within section I of subgenus Blaps, half of the species groups (considering only groups for which we have more than one sampled representative) are recovered monophyletic, namely the species groups alternans, cordicollis, gigas, magica and peyerimhoffi. All species and subspecies for which several representatives are included are recovered monophyletic, with the noticeable exceptions of Blaps approximans Seidlitz, 1893 (due to the placement of an individual of B. haberti Peyerimhoff, 1943) and B. nitens nitens Laporte, 1840 (due to the placement of an individual of $B$. nitens requieni Solier, 1848). Regarding the placement of the new species, it is worth underlining that although Blaps intermedia sp. nov. is morphologically very similar to $B$. debdouensis, it is more closely related to $B$. appendiculata, while $B$. debdouensis is more closely related to $B$. emondi.

\section{Discussion}

The moderate support for our phylogenetic reconstruction can likely be accounted for by the amount of missing data in our dataset, especially given the fact that no molecular data was available for nine taxa. The low rate of PCR success results from the fact that we mostly processed specimens collected more than 10 years ago (PCR failed for more than 50 specimens). Because numerous species of interest are distributed in areas that are now hardly accessible, we think that future phylogenetic studies on species of Blaps (especially for the species that are distributed in Northern Africa) will require the intensive use of museomics approaches (see, e.g., Tin et al. 2014; Kanda et al. 2015).

Though the inferred basal phylogenetic relationships within sampled representatives of the tribe Blaptini are not well supported overall (for instance, the sampled Blaps from section II are recovered monophyletic, but with weak support), the inferred paraphyly of the genus is likely not artefactual. Indeed, its possible paraphyletic status does not come as a surprise given the taxonomic history of the tribe Blaptini, where numerous species were originally described in the genus Blaps, including species that are now assigned to genera belonging to other subtribes (Löbl et al. 2008). As a result, the subtribe Blaptina is possibly also paraphyletic, as it encompasses two clades (one for the sampled representatives of section I and one for the sampled representatives of section II of the subgenus Blaps) that are separated by representatives of three distinct subtribes of Blaptini. Obviously, because two of the three basal nodes are weakly supported, these results should be taken cautiously and highlight the need for more molecular data and a denser sampling for the tribe Blaptini. Since the subtribe Blaptina currently consists of 11 genera, our results emphasize the need for phylogenetic studies with a more comprehensive sampling at the genus level in order to properly redefine the higher systematics of the tribe Blaptini.

Within section I of subgenus Blaps, our results highlight the paraphyletic nature of several species groups. In contrast with the results of Condamine et al. (2013), in this study the alternans group is recovered monophyletic, while the propheta group is recovered paraphyletic due to the placement of individuals of B. tripolitanica Karsch, 1881 . This paraphyly is likely artefactual, and it is only moderately supported in our analyses ( $\mathrm{PP}=0.63$ and 0.72 for the nodes leading to the other representatives of the propheta group). The discrepancies between the two studies probably result from the inclusion of additional taxa and molecular data, in combination with the use of more thorough partitioning strategies. In our study, the lusitanica species group is also recovered paraphyletic as a result of the inclusion of a representative of B. tichyi Martínez Fernández, 2010. With reference to the latter, we think that the position of Blaps tichyi (sister to B. murati Peyerimhoff, 1943) is also artefactual because of the lack of character overlap between the two taxa (no molecular data is available for $B$. murati and, conversely, no morphological data is available for B. tichyi). Regarding the remaining three paraphyletic species groups (bifurcata, emondi and nitens), our results stress the need for a reappraisal of the boundaries of several species groups. For instance, the inclusion of Blaps superstitiosa Erichson, 1841 within the nitens group is to be considered as being based on the results of the molecular analyses, despite the fact that this species does not share the unique synapomorphy of the group (i.e., a straight posterior tibia). Similarly, the inclusion 
of Blaps maroccana Seidlitz, 1893 and B. pinguis Allard, 1880 as members of the emondi group might be warranted, but will require redefining the combination of character states that describe/delineate the clade.

At the species level our phylogenetic framework allows us to discuss the placement of the five newly described species, four of which belong to the emondi group. In the case of Blaps intermedia sp. nov., the results of the phylogenetic analyses support our view of considering this taxon as a distinct species within the emondi group, not directly related to B. debdouensis. The placement of Blaps nitiduloides sp. nov. (clustered with $B$. pinguis) came as a surprise, because this species is morphologically most similar to B. binominata and B. emondi; we cannot exclude that this position is artefactual, especially given the fact that it is only weakly supported $(\mathrm{PP}=0.79)$. Regarding Blaps maldesi sp. nov. and B. teocchii sp. nov., both species are clustered together as sister to all remaining members of the emondi group (plus the only representative of the pinguis group); this placement is not surprising given that both species share unique combinations of character states (see above). Within the gigas group, Blaps effeminata sp. nov. is recovered as sister to a clade encompassing $B$. doderoi and $B$. wiedemannii, while being morphologically closer to $B$. polychresta; that being said, the corresponding node is only weakly supported $(\mathrm{PP}=0.69)$.

Our results also provide further evidence to support the hypothesis that most subspecies of Blaps correspond to distinct valid species; this is especially the case for the subspecies that do not cluster together in the phylogenetic tree, such as B. nefrauensis nefrauensis Seidlitz, 1893 and B. nefrauensis vespertina Koch, 1937, or for the subspecies of $B$. nitens, which do not constitute a monophyletic group due to the placement of individuals of $B$. sulcifera and B. superstitiosa. To advance on this issue, more morphological and molecular studies, as well as the sequencing of additional specimens, are definitely required.

\section{Acknowledgments}

For the loan and examination of material, especially type material, we would like to thank Dr O. Merkl (HNHM), Dr R. Poggi (MCG), Dr H. Labrique (MHNL), Dr C. Girard (MNHN), C. Cocquempot, J.-M. Maldes, M. Martinez, J.C. Martínez Fernández and V. Tichý. Many thanks to F. Soldati for making available numerous interesting specimens. Financial support was provided by the INRA and by the "Bibliothèque du Vivant" program (Project 'Evolution de Communautés aptères d'Insectes endémiques du Pourtour méditerranéen'; CIAM) supported by a joint CNRS, INRA and MNHN consortium. Laboratory facilities were provided by the UMR CBGP in Montferrier-sur-Lez (France). The authors also thank A. Dehne Garcia for his help at the CBGP HPC computational facility. Finally, we would like to thank J.-Y. Rasplus, who handled the manuscript, and two anonymous reviewers for their constructive comments and suggestions on a previous version of the manuscript.

\section{References}

Allard E. 1880. Essai de classification des Blapsides de l'Ancien monde. $1^{\text {re }}$ partie. Annales de la Société Entomologique de France, Series 5 10: 269-320. Available from http://biodiversitylibrary.org/ page/8232117 [accessed 4 Jan. 2017].

Allard E. 1881. Essai de classification des Blapsides de 1'Ancien monde. $2^{\mathrm{e}}$ partie. Annales de la Société Entomologique de France, Series 6 1: 131-180. Available from http://biodiversitylibrary.org/ page/8995848 [accessed 4 Jan. 2017].

Allard E. 1882. Essai de classification des Blapsides de l'Ancien monde. $4^{\mathrm{e}}$ partie. Annales de la Société Entomologique de France, Series 6 2: 77-140. Available from http://biodiversitylibrary.org/ page/8997388 [accessed 4 Jan. 2017]. 
Ardoin P. 1973 Contribution á l'étude des Tenebrionidae (Coleoptera) de Sardaigne. Annales de la Société Entomologique de France, N.S. 9: 257-307.

Castro Tovar A. 2014. Una nueva especie de Blaps Fabricius, 1775 del sureste de España (Coleoptera, Tenebrionidae). Arquivos Entomolóxicos 12: 237-243.

Condamine F.L., Soldati L., Rasplus J.-Y. \& Kergoat G.J. 2011. New insights on systematics and phylogenetics of Mediterranean Blaps species (Coleoptera: Tenebrionidae: Blaptini), assessed through morphology and dense taxon sampling. Systematic Entomology 36: 340-361. http://dx.doi.org/10.1111/ j.1365-3113.2010.00567.x

Condamine F.L., Soldati L., Clamens A.-L., Rasplus J.-Y. \& Kergoat G.J. 2013. Diversification patterns and processes of wingless endemic insects in the Mediterranean Basin: historical biogeography of the genus Blaps (Coleoptera: Tenebrionidae). Journal of Biogeography 40: 1899-1913. http://dx.doi. org/10.1111/jbi.12144

Erixon P., Svennblad B., Britton T. \& Oxelman B. 2003. Reliability of Bayesian posterior probabilities and bootstrap frequencies in phylogenetics. Systematic Biology 52: 665-673. http://dx.doi. org/10.1080/10635150390235485

Gebien H. 1937. Katalog der Tenebrioniden (Col. Heteromera). Teil 1. Pubblicazioni del Museo entomologico Pietro Rossi 2: 505-883.

Kanda K., Pflug J.M., Sproul J.S., Dasenko M.A. \& Maddison D.R. 2015. Successful recovery of nuclear protein-coding genes from small insects in museums using Illumina sequencing. PLoS One 10: e0143929. http://dx.doi.org/10.1371/journal.pone.0143929

Kergoat G.J., Soldati L., Clamens A.-L., Jourdan H., Zahab R., Genson G., Bouchard P. \& Condamine F.L. 2014a. Higher-level molecular phylogeny of darkling beetles (Coleoptera, Tenebrionoidea, Tenebrionidae). Systematic Entomology 39: 486-499. http://dx.doi.org/10.1111/syen.12065

Kergoat G.J., Bouchard P., Clamens A.-L., Abbate J.L., Jourdan H., Jabbour-Zahab R., Genson G., Soldati L. \& Condamine F.L. 2014b. Cretaceous environmental changes led to high extinction rates in a hyperdiverse beetle family. BMC Evolutionary Biology 14: e220. http://dx.doi.org/10.1186/s12862$\underline{014-0220-1}$

Lanfear R., Calcott B., Ho S.Y.W. \& Guindon S. 2012. PartitionFinder: combined selection of partitioning schemes and substitution models for phylogenetic analyses. Molecular Biology and Evolution 29: 1695701. http://dx.doi.org/10.1093/molbev/mss020

Lewis P.O. 2001. A likelihood approach to estimating phylogeny from discrete morphological character data. Systematic Biology 50: 913-925. http://dx.doi.org/10.1080/106351501753462876

Löbl I., Nabozhenko M. \& Merk1 O. 2008. Family Tenebrionidae Latreille, 1802. In: Löbl I. \& Smetana A. (eds) Catalogue of Palaearctic Coleoptera, Tenebrionoidea, Vol. 5: 219-238. Apollo Books. Stenstrup, Denmark.

Martínez Fernández J.C. 2010. Un nuevo representante del género Blaps Fabricius, 1775 de la Península Ibérica: Blaps tichyi n. sp. (Coleoptera, Tenebrionidae). Boletín de la Sociedad Entomológica Aragonesa 47: $181-185$.

Matthews E.G., Lawrence J.F., Bouchard P., Steiner W.E. \& Ślipiński S.A. 2010. Chapter 11.14. Tenebrionidae Latreille, 1802. In: Leschen R.A.B., Beutel R.G. Lawrence J.F. (eds) Handbook of Zoology. A Natural History of the Phyla of the Animal Kingdom, Vol. IV-Arthropoda: Insecta. Part 38. Coleoptera, Beetles, Vol. 2: Systematics (Part 2): 574-659. Walter de Gruyter, Berlin.

Medvedev G.S. 2000. Genera of tenebrionid beetles of the tribe Blaptini (Coleoptera, Tenebrionidae). Entomological Review 79: 643-663. 
SOLDATI L. et al., Blaps systematics and taxonomy

Medvedev G.S. 2001. Evolution and system of darkling beetles of the tribe Blaptini (Coleoptera, Tenebrionidae). Chteniya Pamyati Nikolaya Aleksandrovicha Kholodkovskogo 53: 1-332.

Medvedev G.S. 2007. A contribution to the taxonomy and morphology of the tribe Blaptini (Coleoptera, Tenebrionidae). Entomological Review 87: 181-214. http://dx.doi.org/10.1134/S0013873807020078

Medvedev G.S. \& Merkl O. 2002. Viettagona vietnamensis gen. et sp. n. from Vietnam (Coleoptera, Tenebrionidae: Blaptini). Acta Zoologica Academiae Scientiarum Hungaricae 48: 317-332.

Nylander J.A.A., Ronquist F., Huelsenbeck J.P. \& Nieves-Aldrey J.L. 2004. Bayesian phylogenetic analysis of combined data. Systematic Biology 53:47-67.http://dx.doi.org/10.1080/10635150490264699

Ripplinger J. \& Sullivan J. 2008. Does choice in model selection affect maximum likelihood analysis? Systematic Biology 57: 76-85. http://dx.doi.org/10.1080/10635150801898920

Ronquist F., Teslenko M., van der Mark P., Ayres D.L., Darling A., Höhna S., Larget B., Liu L., Suchard M.A. \& Huelsenbeck J.P. 2012. MrBayes 3.2: efficient Bayesian phylogenetic inference and model choice across a large model space. Systematic Biology 61: 539-542. http://dx.doi.org/10.1093/sysbio/ sys029

Seidlitz G.C.M. von. 1893. Naturgeschichte der Insekten Deutschlands. Erste Abteilung, Coleoptera, 1896 Edition. Nicolaische Verlags-Buchhandlung, Berlin.

Ślipiński S.A., Leschen R.A.B. \& Lawrence J.F. 2011. Order Coleoptera Linnaeus, 1758. In: Zhang Z.-Q. (ed.) Animal Biodiversity: an Outline of Higher-Level Classification and Survey of Taxonomic Richness. Zootaxa 3148: 203-208.

Soldati L. 1994. Révision des Blaps du nord de l'Afrique: les espèces du groupe alternans Brullé (Coleoptera, Tenebrionidae). Bulletin de la Société Entomologique de France 99: 117-125.

Soldati L., Kergoat G.J. \& Condamine F.L. 2009. Important notes on taxonomic structure of Blaps nitens Laporte de Castelnau, 1840 with the description of new subspecies Blaps nitens medvedevi subsp. $\mathrm{n}$. (Coleoptera: Tenebrionidae: Blaptini). Caucasian Entomological Bulletin 5: 231-234.

Solier M. 1848. Essai de classification des Collaptèrides Blapsites. In: Baudi F. \& Truqui E. (eds) Studi Entomologici 1: 1-376. Torino.

Tin M.M.-Y., Economo E.P. \& Mikheyev A.S. 2014. Sequencing degraded DNA from non-destructively sampled museum specimens for RAD-tagging and low-coverage shotgun phylogenetics. PLoS ONE 9: e96793. http://dx.doi.org/10.1371/journal.pone.0096793

Manuscript received: 23 January 2016

Manuscript accepted: 1 August 2016

Published on: 20 February 2017

Guest editors: Line Le Gall, Frédéric Delsuc, Stéphane Hourdez, Guillaume Lecointre

and Jean-Yves Rasplus

Desk editor: Danny Eibye-Jacobsen

Printed versions of all papers are also deposited in the libraries of the institutes that are members of the EJT consortium: Muséum national d'Histoire naturelle, Paris, France; Botanic Garden Meise, Belgium; Royal Museum for Central Africa, Tervuren, Belgium; Natural History Museum, London, United Kingdom; Royal Belgian Institute of Natural Sciences, Brussels, Belgium; Natural History Museum of Denmark, Copenhagen, Denmark; Naturalis Biodiversity Center, Leiden, the Netherlands. 


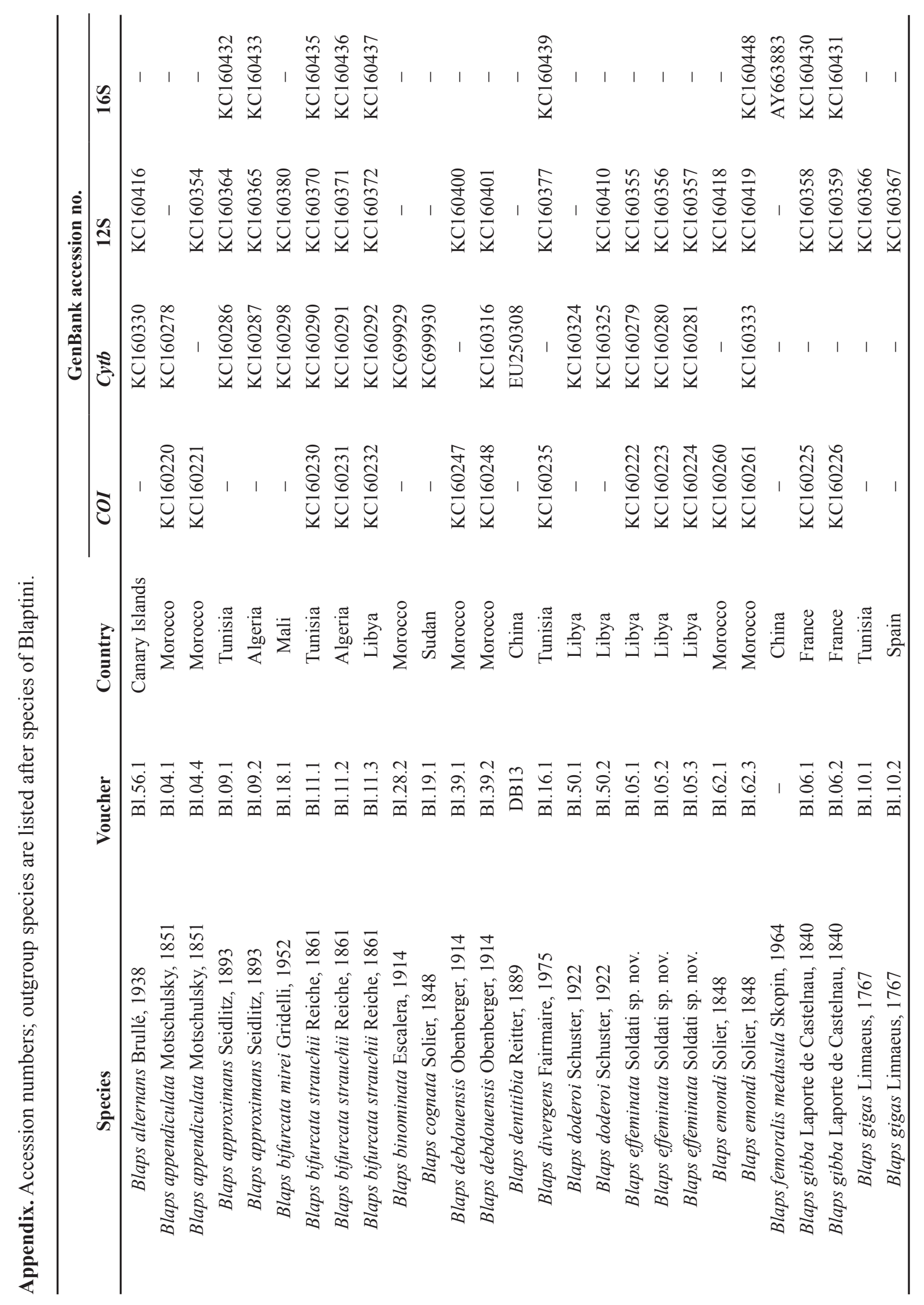




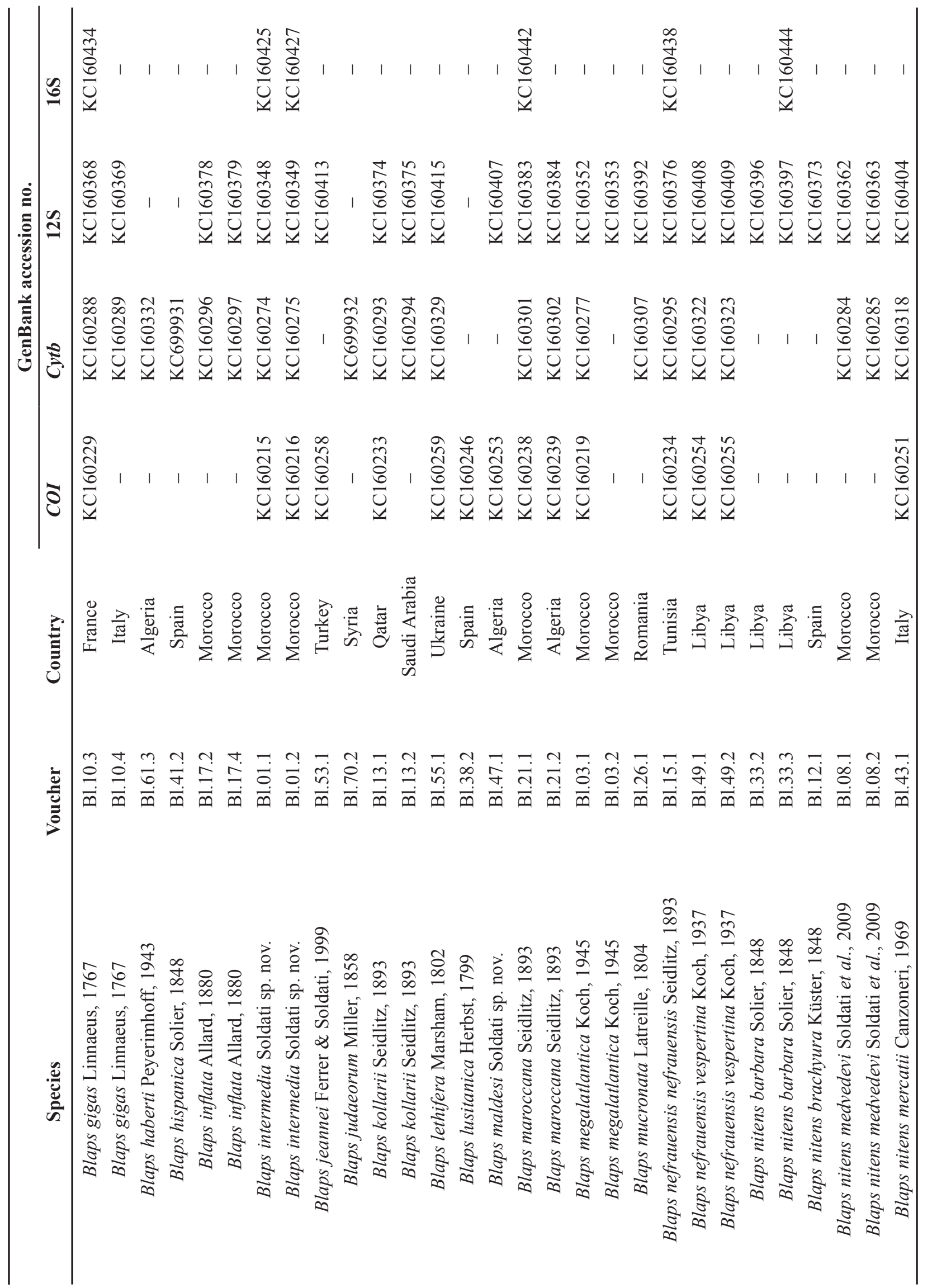




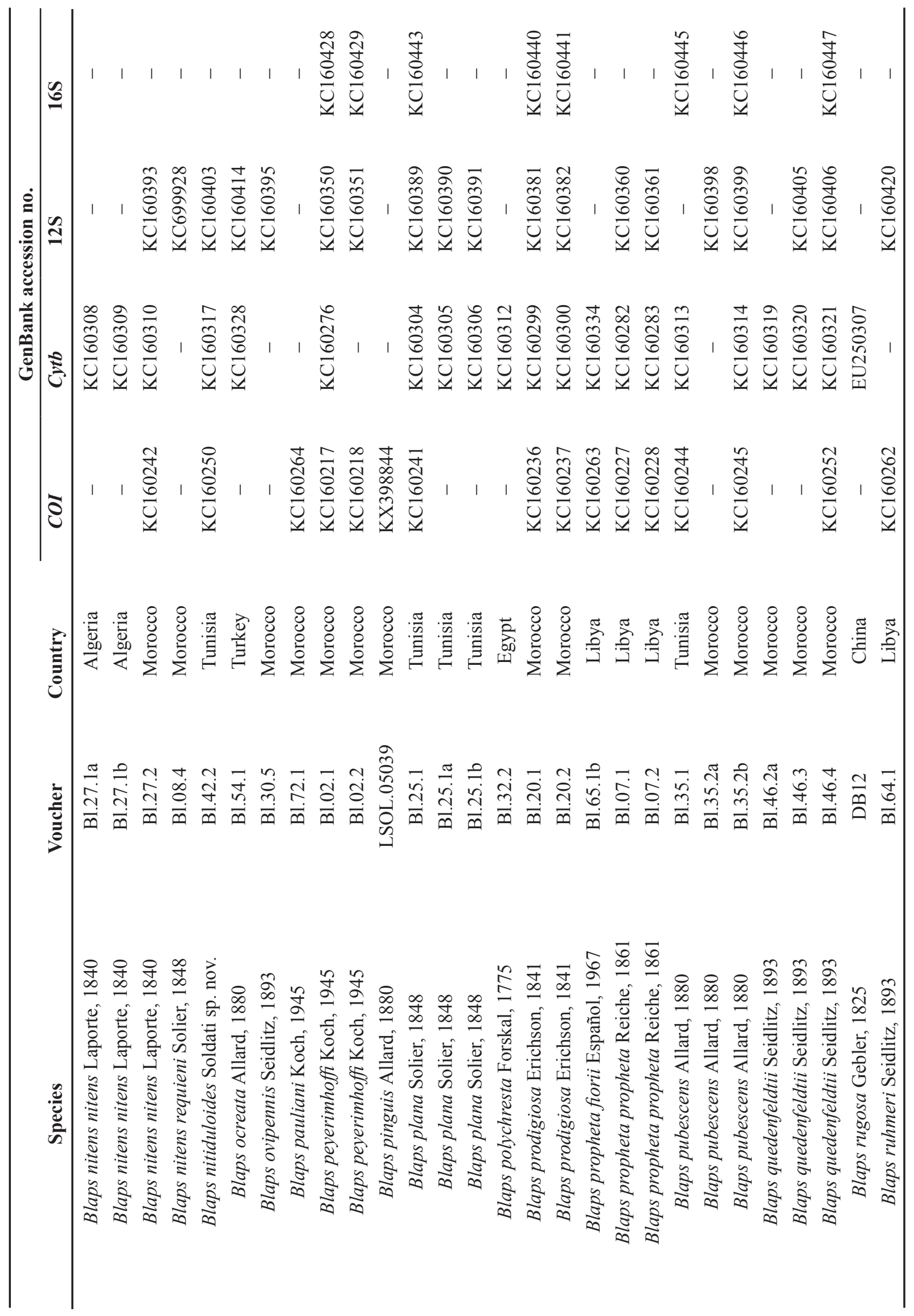




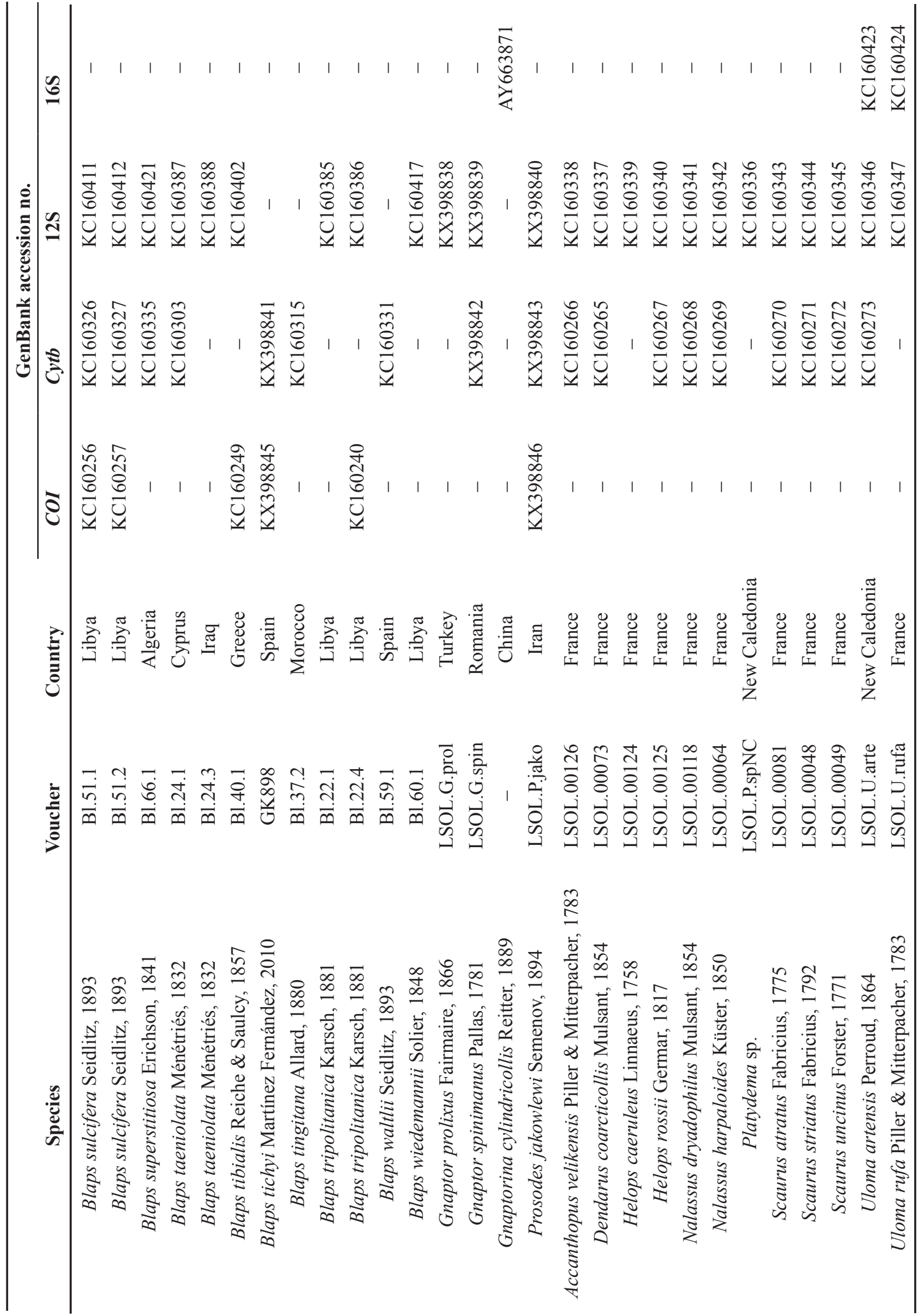

